\title{
Crystallization history of Oligocene ijolitic rocks from the Doupovské hory Volcanic Complex (Czech Republic)
}

\author{
Jakub HALODA ${ }^{1 *}$, Vladislav RAPPRICH${ }^{1}$, František V. HOLUB², Patricie HALODOVÁ1, \\ Tomáš VACULOVIČ
}

\author{
${ }^{1}$ Czech Geological Survey, Klárov 3, 11821 Prague 1, Czech Republic; jakub.haloda@geology.cz \\ ${ }^{2}$ Institute of Petrology and Structural Geology, Faculty of Science, Charles University, Albertov 6, 12843 Prague 2, Czech Republic \\ ${ }^{3}$ Institute of Chemistry, Faculty of Science, Masaryk University, Kotlářská 2, 61137 Brno, Czech Republic \\ * Corresponding author
}

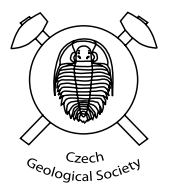

Ijolitic rocks of the Flurbühl Composite Intrusion rank to the most primitive intrusive rocks found within the Doupovské hory Volcanic Complex. Studies of mineral chemistry together with crystallization modelling of melteigite and ijolite brought new information about the evolution of ijolitic magmas and their ascent. Crystallization modelling affirms the absence of accumulated minerals and confirms that the recalculated major-element bulk-rock analyses reflect the compositions of their original parental magmas accurately. Melteigite developed by early equilibrium crystallization under pressure of approximately $4 \mathrm{kbar}$ (estimated minimum cooling rate is $\sim 0.02{ }^{\circ} \mathrm{C} / \mathrm{hr}$ ) and subsequent fractional crystallization under much lower pressure ( $\sim 0.2 \mathrm{kbar})$. Ijolite originated by fractional crystallization of a slightly more evolved magma batch under lower pressures probably at the final emplacement level. The results of crystallization modelling and estimates of REE contents in parental melts suggest a close genetic relationship between both rock suites. The olivine-bearing melteigite was postulated as a possible parental magma composition for derivation of the olivine-free ijolite.

Keywords: Nephelinolite, melteigite, ijolite, crystallization modelling, fractional crystallization, Doupovské hory Mts. Received: 16 April 2010; accepted: 19 September 2010; handling editor: D. Dolejš

\section{Introduction}

High-level intrusions are rather common in mafic alkaline volcanic complexes. However, they are mostly hidden and even where they crop out thanks to advanced erosion of the volcanic edifices, their original features are frequently obscured by alteration processes. Therefore, detailed research and models of magmatic evolution in such intrusions are rather scarce.

We have investigated intrusive rocks from the central part of the Doupovské hory Volcanic Complex (the Flurbühl Composite Intrusion) that provide the possibility to study the sub-surface magmatic processes related to formation and evolution of the still preserved superficial volcanic complex. The petrology and bulk-rock chemistry of the entire subvolcanic suite with two observed differentiation trends is described by Holub et al. (this volume). From the whole association of alkaline rocks we selected for detailed examination of mineral chemistry and crystallization history the very fresh ijolitic rocks with nearly anhydrous mineral assemblages.

The major aims of this contribution are to unravel the crystallization history of these intrusive rocks rich in mafic minerals, to evaluate a possible role of mafic mineral accumulation in the genesis of the melteigite, and to decipher its relationship to ijolites with lower abundances of the mafic phases.

\section{Geological setting}

The Doupovské hory Volcanic Complex (DHVC) occupies the western part of the northeast-southwesttrending Eger (Ohře) Graben (EG) in northwestern Bohemia (Czech Republic; Fig. 1). The EG belongs to the system of Cenozoic rifts in central and western Europe (European Cenozoic Rift System sensu Dèzes et al. 2004 - ECRIS). The EG follows the older Variscan suture between the Saxothuringian and Teplá-Barrandian domains (Babuška et al. 2010; Mlčoch and Konopásek 2010) in the northwestern part of the Bohemian Massif. It is interpreted as an incipient rift structure formed during two distinct phases of extension (Rajchl et al. 2009). The first phase lasted from the late Eocene until the early Miocene. It was characterised by the NNE-SSW to N-S oriented horizontal extension, oblique to the rift axis. The palaeostress field of the oblique extension most probably reflected lithospheric doming due to thermal perturbation of the lithosphere (Dèzes et al. 2004), which resulted also in extensive OIB-like magmatism within the EG. The later, orthogonal extensional phase is explained by stretching along the crest of a growing regional-scale anticlinal feature, which supports the recent hypothesis of the lithospheric folding in the Alpine-Carpathian foreland (Dèzes et al. 2004; Bourgeois et al. 2007; Rajchl et al. 2009). 


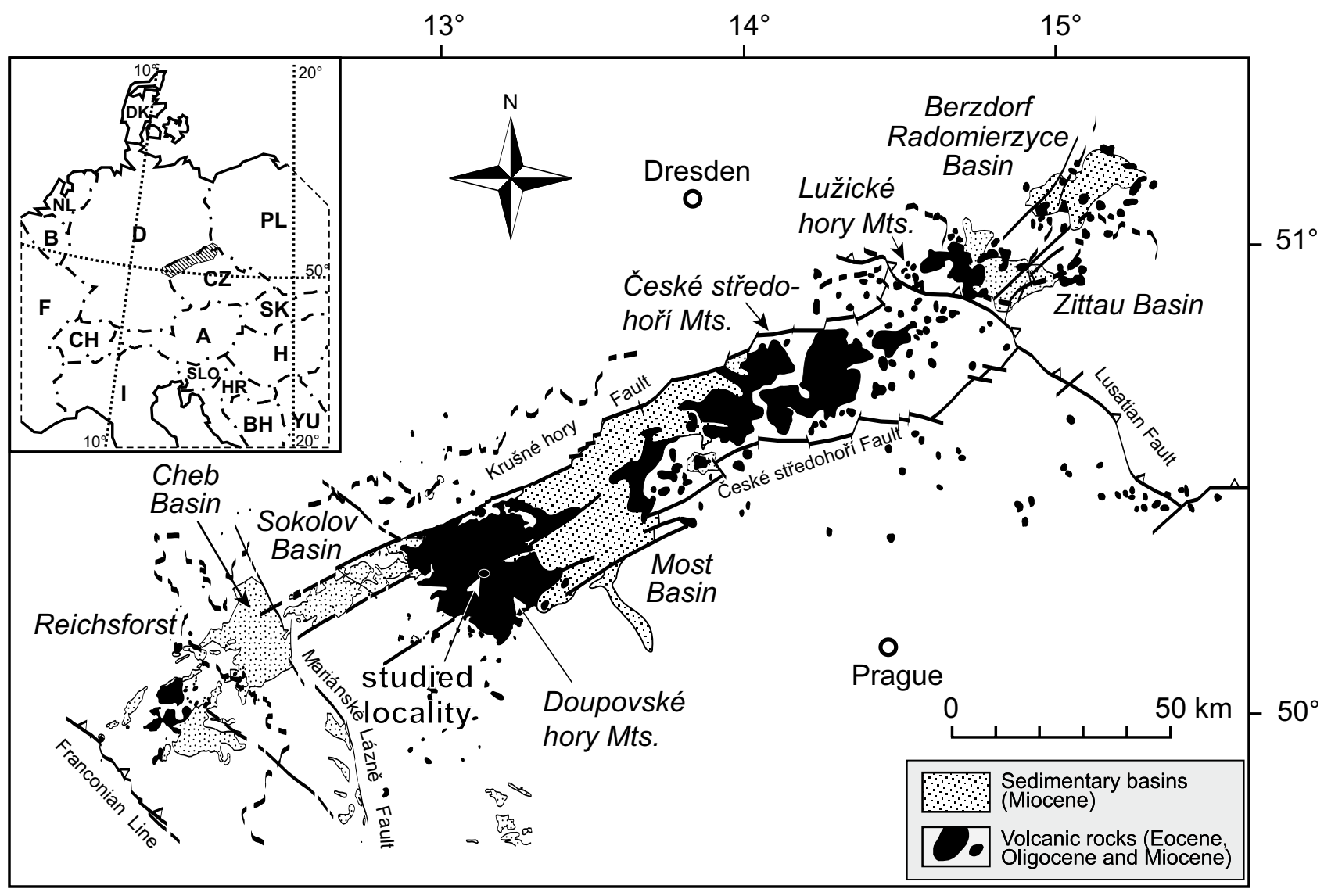

Fig. 1 Location of the Doupovské hory Volcanic Complex and the Flurbühl Composite Intrusion.

The volcanic activity of the DHVC started in the earliest Oligocene (mammal zone MP-21; Fejfar and Kaiser 2005) and lasted until the early Miocene (Rapprich and Holub 2008). The Flurbühl body, which also includes the studied ijolites, intruded into the early DHVC volcanic edifice at about 29-30 Ma (Holub et al. this volume).

The setting and composition of the DHVC are similar to many other Cenozoic intra-plate volcanic complexes of central and western Europe (The Circum-Mediterranean Anorogenic Cenozoic Igneous Province sensu Lustrino and Wilson 2007 - CiMACI). The DHVC is dominated by mafic alkaline lavas corresponding to (olivine-) foidites, basanites, tephrites and picrobasalts to alkali basalts. Moderately differentiated rocks (trachybasalts to trachyandesites) are subordinate and phonolitic rocks occur only scarcely, mostly in the form of NW-SE trending dykes (Skácelová et al. 2009). Subvolcanic rocks building up the Flurbühl body (Wiesbaur 1901) are represented by clinopyroxenites, various nephelinolites (melteigite to ijolite with rare urtite), essexite, sodalite monzodiorite to monzosyenite and sodalite syenite (Holub et al. this volume).

Most of the mafic volcanic and intrusive rocks are depleted in compatible elements $(\mathrm{Cr}, \mathrm{Ni})$ suggesting that these rocks already experienced significant crystal fractionation. The most mafic rocks with the highest $\mathrm{mg} \#$ values and compatible element contents are picrobasalts. However, abundance of large olivine and clinopyroxene phenocrysts (exceeding $1 \mathrm{~cm}$ ) together with positive correlation between $\mathrm{SiO}_{2}$ and $\mathrm{MgO}$ point to a semi-cumulate origin of these rocks (Rapprich and Holub 2008).

Among intrusive rocks of the Flurbühl body, the most mafic, apart from the extremely heterogeneous clinopyroxenite breccias, are ijolitic rocks, namely the olivine-bearing melteigite (melanephelinolite). Though these rocks are present at the current surface only as loose blocks, local road construction works temporarily exposed two types of these primitive alkaline intrusive rocks at the eastern margin of the Flurbühl Intrusion. The first type, olivinebearing melteigite, is described in Holub et al. (this volume) as samples DH1330 and DH1319A. The second type, olivine-free ijolite, is represented by their sample DH1329.

\section{Methods}

\subsection{Scanning electron microscopy and microanalysis}

Two polished thin sections $(21 \times 34 \mathrm{~mm}$ and $20 \times 38 \mathrm{~mm})$ from an olivine-bearing melteigite and one $(24 \times 38 \mathrm{~mm})$ 
from an olivine-free ijolite were prepared. Textural and mineralogical characteristics were studied using a LEICA DMLP petrographic microscope.

Backscattered electron (BSE) images and elemental $\mathrm{X}$-ray intensity maps were produced using a CamScan 3200 scanning electron microscope fitted with an Oxford Instruments Energy Dispersive Spectral unit at the Czech Geological Survey in Prague. The elemental X-ray maps were generated using an accelerating voltage of $20 \mathrm{kV}$ and $25 \mathrm{nA}$ beam current. Mineral modes were determined using the Area Measurement software (Oxford Instruments) and digital processing of BSE images and elemental X-ray maps.

Mineral compositions were acquired using quantitative X-ray wavelength dispersive spectral analysis on an MICROSPEC 3PC X-ray wavelength dispersive system on a CamScan 3200 scanning electron microscope at the Czech Geological Survey. The analyses were performed using an accelerating voltage of $15 \mathrm{kV}, 20 \mathrm{nA}$ beam current, $1 \mu \mathrm{m}$ beam size and ZAF correction procedures. The counting times were 20 or $30 \mathrm{~s}$ for all analyzed elements. To avoid Na volatilization during the analysis of nepheline and sanidine, the beam diameter was defocused to 5 $\mu \mathrm{m}$. A combination of natural and synthetic standards was used for calibration. Relative uncertainties are calculated to be less than $1 \%$ at the $>10$ wt. $\%$ level, $<12 \%$ at the $\sim 1$ wt. $\%$ level and $>20 \%$ at the $<0.5$ wt. $\%$ level.

\subsection{Electron backscattered diffraction}

Crystallographic orientations of olivine were determined by electron backscattered diffraction (EBSD). The thin sections used for EBSD applications were prepared by the process of chemo-mechanical polishing using colloidal silica suspension. The crystallographic orientation data were obtained from automatically indexed EBSD patterns collected by a HKL Technology Nordlys II EBSD system (Schmidt and Olensen 1989) on a CamScan 3200 scanning electron microscope at the Czech Geological Survey. Analytical conditions were $33 \mathrm{~mm}$ working distance, $20 \mathrm{kV}$ accelerating voltage and $5.0 \mathrm{nA}$ beam current. Obtained EBSD patterns were indexed by using the CHANNEL 5 software from HKL Technology.

\subsection{Laser ablation ICP-MS}

The concentrations of selected trace elements (including REE) in clinopyroxene and olivine phenocrysts were analysed by mass spectrometer with inductively coupled plasma equipped with laser ablation (LA-ICP-MS) hosted at the Institute of Chemistry, Masaryk University in Brno. Instrumentation for LA-ICP-MS consists of a laser ablation system UP 213 (New Wave, USA) and an ICP-MS spectrometer Agilent 7500 CE (Agilent, Japan). A commercial Q-switched Nd:YAG laser ablation device works at the $5^{\text {th }}$ harmonic frequency which corresponds to the wavelength of $213 \mathrm{~nm}$. The ablation device is equipped with programmable XYZ-stages to move the sample along a programmed trajectory during ablation. Target visual inspection as well as photographic documentation is accomplished by means of a built-in microscope/CCDcamera system. A sample was enclosed in the SuperCell (New Wave, USA) and was ablated by the laser beam, which was focused onto the sample surface through a quartz window. The ablation cell was flushed with helium (carrier gas), which transported the laser-induced aerosol to the inductively coupled plasma. A sample gas flow of argon was admixed to the helium carrier gas flow behind the laser ablation cell to achieve the total gas flow of $1.6 \mathrm{l} / \mathrm{min}$.

For LA-ICP-MS measurements, a hole drilling mode (fixed sample position during laser ablation) was used for $60 \mathrm{~s}$ at each spot. Laser ablation was performed with a laser spot diameter $65 \mu \mathrm{m}$, laser fluence $5.0 \mathrm{~J} \mathrm{~cm}^{-2}$ and repetition rate $10 \mathrm{~Hz}$. The NIST612 glass standard (Hollocher and Ruiz 1995) was used for calibration purposes.

\section{Results}

\subsection{Petrography and mineral chemistry}

\subsubsection{Melteigite}

The studied melteigite (olivine-bearing melanephelinolite; samples DH1330 and DH1319A) has a coarsegrained porphyritic magmatic texture consisting mainly of clinopyroxene (63 vol. \%), olivine (4 vol. \%), Ti-rich magnetite (5 vol. \%), nepheline (18 vol. \%) and sanidine (7 vol. \%) (Fig. 2). Accessory minerals include apatite $(0.9$ vol. \%), ilmenite ( 1 vol. \%), rare chromite, titanite ( $<0.1$ vol. \%), Mg-biotite ( 1 vol. \%), analcime, and rare calcite. The distribution of silicate minerals is relatively homogeneous.

Olivine. Olivine in the melteigite forms euhedral to subhedral phenocrysts $(1.8-4.0 \mathrm{~mm}$, typically $>2.5 \mathrm{~mm})$ with equant shapes. The olivine grains show normal symmetric zoning with Mg-rich cores and less magnesian rims (Fig. 2c). The early-formed olivines often have inclusions of chromite or crystallized melt inclusions consisting of fine-grained clinopyroxene, nepheline, Tirich magnetite, ilmenite and apatite.

Electron microprobe data of 48 olivine spot analyses were collected to obtain the true range of Fo component $\left(\mathrm{Fo}_{\text {85.5-72.3 }}\right)$. Representative compositions of olivine are listed in Tab. 1. Variation of Fo component within select- 

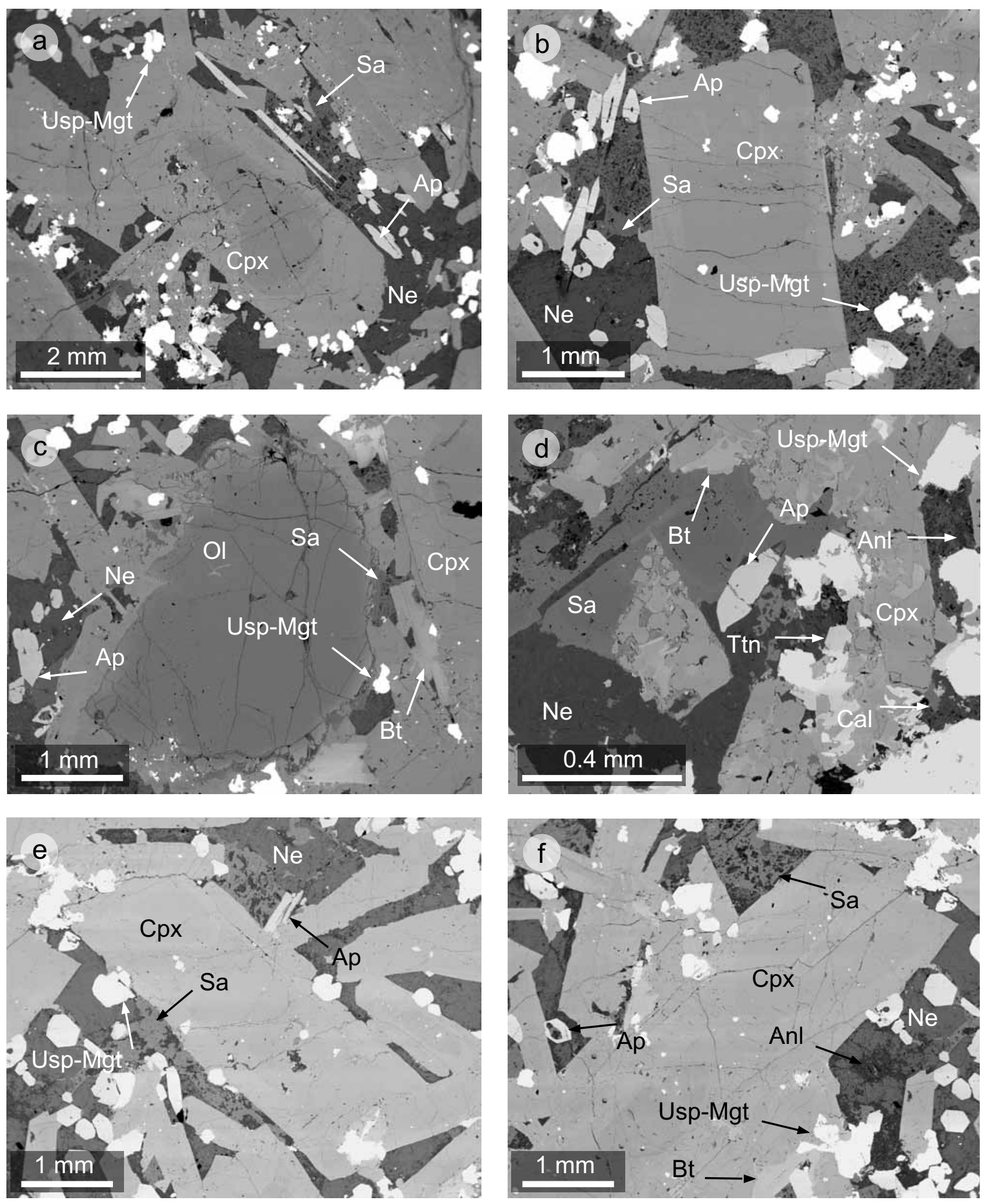

Fig. 2 Back-scattered electron images illustrating the texture and mineralogy of the studied samples. Melteigite: a-b - Coarse-grained magmatic texture with zoned pyroxene phenocrysts; $\mathbf{c}$ - Detailed view of a large zoned olivine phenocryst; $\mathbf{d}$ - Detailed view of late-stage mineral association. Ijolite: e - Coarse-grained magmatic texture with clinopyroxene phenocryst; $\mathbf{f}$ - Detail of a large zoned clinopyroxene phenocryst. Mineral abbreviations after Kretz (1983). 


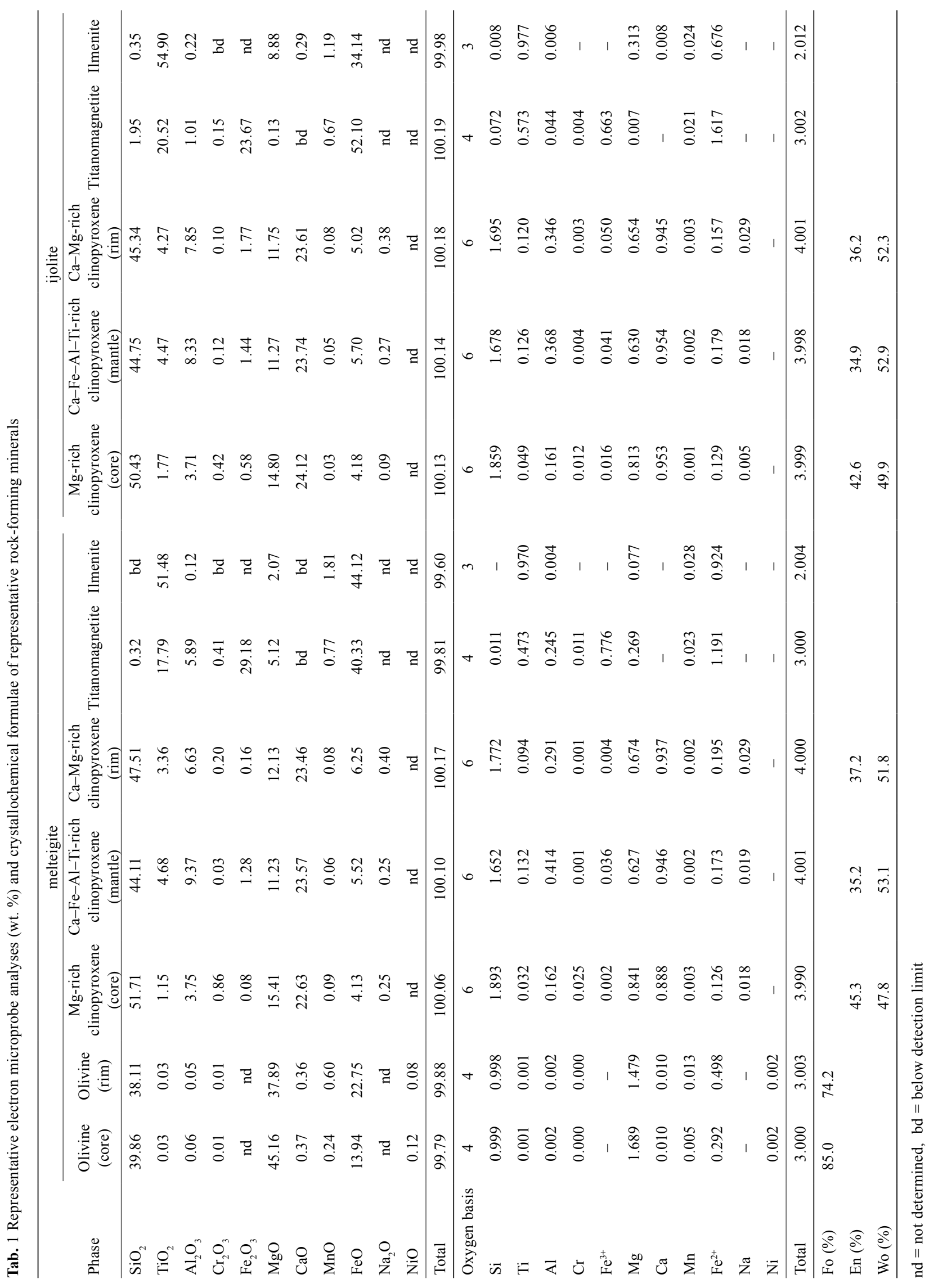


ed single olivine grain was also investigated along two orthogonal profiles (see section 4.3 for more discussion). A BSE image of the measured olivine grain is shown in Fig. $3 \mathrm{a}$ and variation of Fo component within this grain is plotted in Fig. $3 \mathrm{~b}-\mathrm{c}$.

Concentrations of $\mathrm{CaO}$ vary from 0.29 to $0.42 \mathrm{wt} . \%$, $\mathrm{TiO}_{2}$ is less than 0.03 wt. $\%, \mathrm{Cr}_{2} \mathrm{O}_{3}$ is below 0.01 wt. \% and the $\mathrm{MnO}$ range is $0.11-0.60 \mathrm{wt} . \%$.

Clinopyroxene. Clinopyroxene is the most abundant mineral phase, occurring mainly as euhedral, elongated phenocrysts $(3-7.5 \mathrm{~mm})$ and also as finer later crystallized euhedral and subhedral grains (Fig. 2a-b). All clinopyroxenes are characterized by remarkable symmetric chemical zoning. Clinopyroxenes contain inclusions of common Ti-rich magnetite, as well as of rare chromite and apatite.

The chemical composition of clinopyroxene shows strong variations in terms of $\mathrm{Mg}, \mathrm{Fe}, \mathrm{Si}, \mathrm{Al}$ and $\mathrm{Ti}$ contents (Fig. 4). Representative analyses of the main compositional types of clinopyroxene are listed in Tab. 1. Two representative orthogonal chemical profiles across one selected clinopyroxene phenocryst are shown in Fig. 4. Characteristic zoning of the earliest formed clinopyroxene phenocrysts is represented by $\mathrm{Mg}$-rich diopsidic cores with very homogeneous compositions $\left(\mathrm{En}_{45}, \mathrm{Wo}_{48}\right)$, mantles enriched in $\mathrm{Ca}, \mathrm{Fe}, \mathrm{Al}$ and $\mathrm{Ti}$ $\left(\mathrm{En}_{35-40}, \mathrm{Wo}_{50-53}\right)$ and rims enriched in $\mathrm{Ca}$ and $\mathrm{Mg}\left(\mathrm{En}_{35-37}\right.$, $\mathrm{Wo}_{53-52}$ ). The core-to-mantle enrichment in $\mathrm{Ca}, \mathrm{Fe}, \mathrm{Al}$ and $\mathrm{Ti}$ of clinopyroxene grains is not continuous. This feature reflects a discontinuity in the chemical composition between $\mathrm{Mg}$-rich diopside and $\mathrm{Al}$-Ti-rich diopside (Fig. 4). The majority of clinopyroxene phenocrysts, and all clinopyroxene grains that crystallized later, have the composition of $\mathrm{Ca}-\mathrm{Fe}-\mathrm{Al}-\mathrm{Ti}$-rich diopside and do not contain Mg-enriched diopsidic cores. The wollastonite content of the $\mathrm{Ca}-\mathrm{Fe}-\mathrm{Al}-\mathrm{Ti}$-rich diopside is generally higher than $50 \mathrm{~mol}$. \% due to extreme enrichment in nonquadrilateral components ( $\mathrm{Al}$ and $\mathrm{Ti}$ in Ca-Tschermak's molecules - e.g., Rapprich 2005) and such diopside shows depletion in $\mathrm{Si}$.

The chemical composition of Mg-rich diopsidic clinopyroxene cores can be used for estimation of pressure at the time of their initial crystallization from the parental magma. We employed the method of Nimis (2007) based on element occupation of clinopyroxene structural positions. It yielded approximately 4 kbar for the early crystallized Mg-rich cores of larger clinopyroxene crystals and also for Mg-rich clinopyroxene inclusions in olivine. This estimation can be interpreted as the prevailing pressure during initial clinopyroxene crystallization from the parental melt in a relatively deep-seated magma chamber.

Ti-rich magnetite. Ti-rich magnetite in the melteigite occurs as euhedral and subhedral grains $(100-500 \mu \mathrm{m})$, commonly with exsolved ilmenite. Representative com- positions of Ti-rich magnetite, ulvöspinel and exsolved ilmenite are given in Tab. 1. Early crystallized cores have ulvöspinel compositions typically of $\mathrm{Mgt}_{35} \mathrm{Usp}_{65}$.

\subsubsection{Ijolite}

The ijolite has a coarse-grained porphyritic magmatic texture similar to that of the melteigite (Fig. 2e-f) and is dominated by clinopyroxene ( 58 vol. \%) but free of olivine. Other rock-forming minerals are Ti-rich magnetite (4 vol. \%), nepheline (24 vol. \%), sanidine (8 vol. \%) and apatite (1.5 vol. \%). Accessory minerals include Mg-rich biotite $(3$ vol. $\%)$, ilmenite $(1$ vol. $\%)$, titanite $(<0.1$ vol. \%), analcime and rare calcite. Similarly to the melteigite, the ijolite is homogeneous at the thin-section scale.

Clinopyroxene. Clinopyroxene is the most abundant phase occurring mainly as euhedral, elongated phenocrysts $(3.5-7 \mathrm{~mm})$ (Fig. 2e-f) and also as smaller later crystallized euhedral and subhedral grains. All clinopyroxenes possess characteristic symmetric chemical zoning with significant sector zoning (hourglass structure).

The chemical composition of ijolite clinopyroxenes varies widely in terms of $\mathrm{Mg}, \mathrm{Fe}, \mathrm{Si}, \mathrm{Al}$, and $\mathrm{Ti}$ contents (Fig. 5). However these are much smaller than the compositional variations of the melteigite clinopyroxene (Fig. 4). Representative compositions of the main types of clinopyroxene are listed in Tab. 1. Two representative orthogonal chemical profiles across one selected clinopyroxene phenocryst are shown in Fig. 5. The characteristic zoning of the clinopyroxene phenocrysts is represented by $\mathrm{Mg}$-enriched, homogeneous diopsidic cores $\left(\mathrm{En}_{43-41}, \mathrm{Wo}_{50-51}\right)$, mantles rich in $\mathrm{Ca}, \mathrm{Fe}, \mathrm{Al}$ and $\mathrm{Ti}$ $\left(\mathrm{En}_{40-35}, \mathrm{Wo}_{51-53}\right)$ and $\mathrm{Ca}-\mathrm{Mg}$-rich rims $\left(\mathrm{En}_{36-37}, \mathrm{Wo}_{52-51}\right)$. All ijolite clinopyroxenes are richer in $\mathrm{Ca}, \mathrm{Fe}, \mathrm{Al}$, and $\mathrm{Ti}$ than those in the melteigite.

Ti-rich magnetite. Ti-rich magnetite in ijolite occurs as euhedral and subhedral grains $(80-500 \mu \mathrm{m})$, commonly with exsolved ilmenite. Representative compositions of Ti-rich magnetite, ulvöspinel and exsolved ilmenite are listed in Tab. 1. Early crystallized cores have ulvöspinel compositions typically of $\mathrm{Mgt}_{32} \mathrm{Usp}_{68}$.

\subsection{Crystallization modelling}

\subsubsection{Melteigite}

For crystallization modelling we used whole-rock analyses by Holub et al. (in this volume). These were recalculated on the basis of total $\mathrm{FeO}$, whereby the proportion of $\mathrm{Fe}_{2} \mathrm{O}_{3}$ was adjusted to the oxygen fugacity value used for the modelling (Tab. 2). Roeder and Emslie (1970) showed that the distribution coefficient $\mathrm{K}_{\mathrm{d}}$ for partitioning of iron and magnesium between olivine and a co-existing liquid 

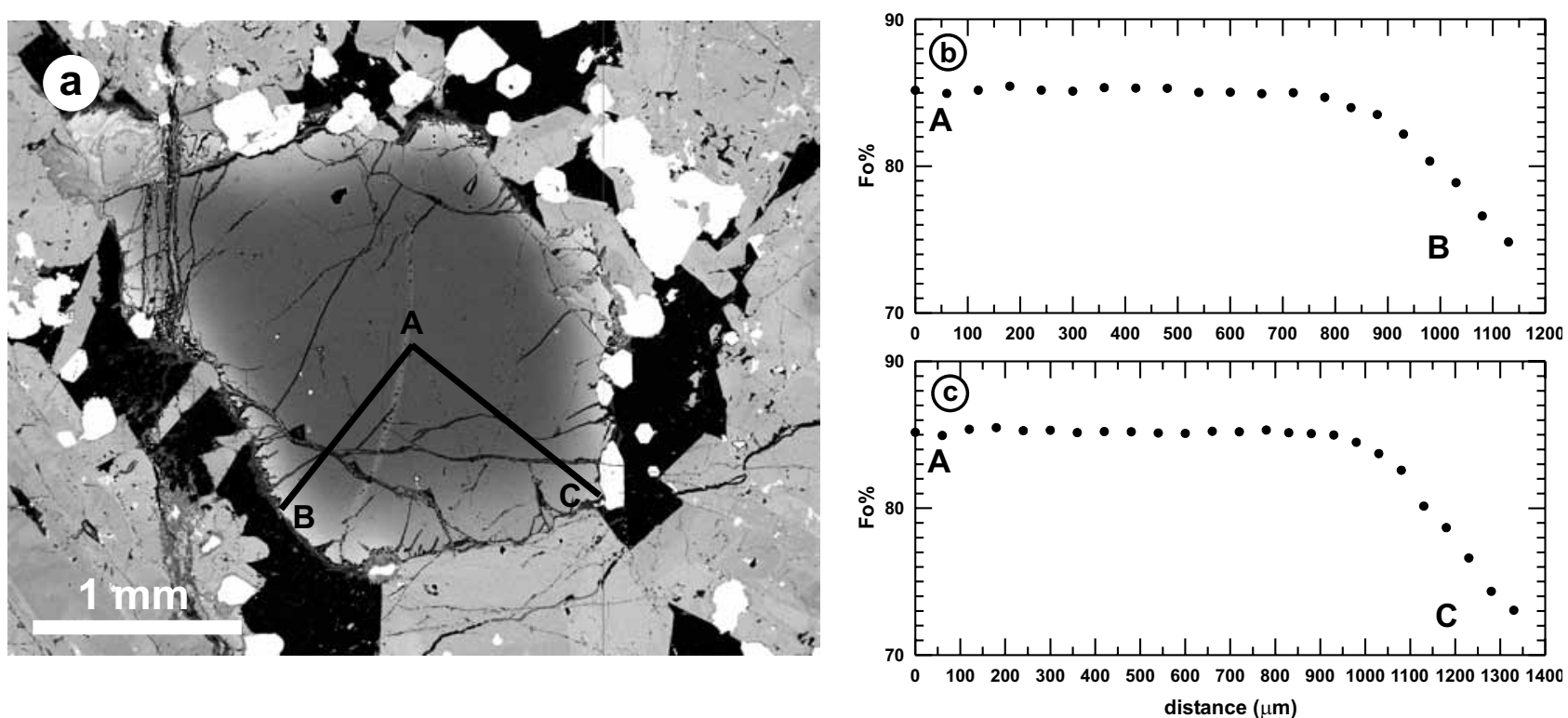

Fig. 3a Back-scattered electron image of single olivine grain from melteigite with lines indicating two orthogonal profiles chosen for investigation of the chemical zoning; b-c - Plots of Fo content variations along these profiles A-B and A-C.
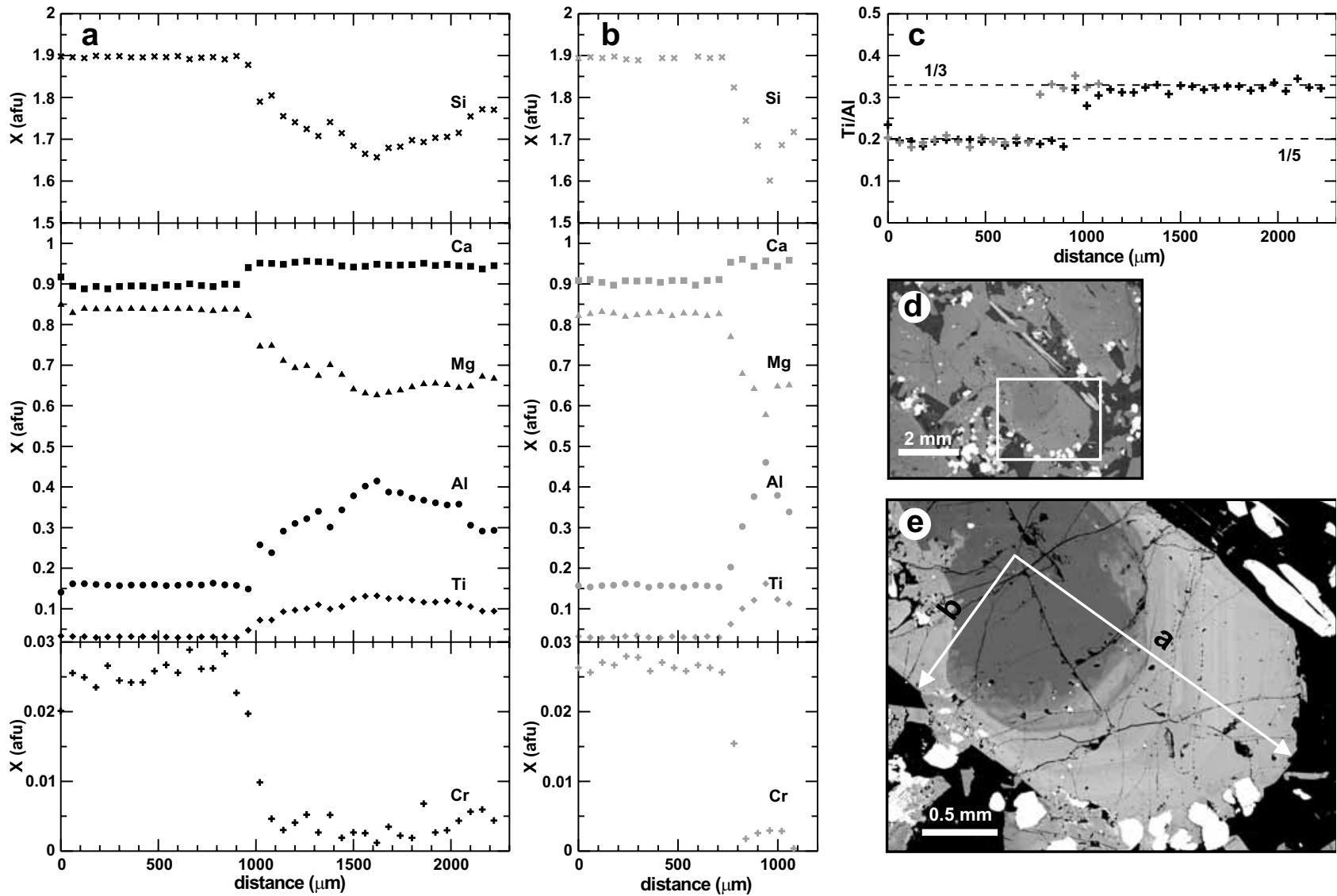

Fig. 4a-b Chemical variation of clinopyroxene from melteigite along two orthogonal profiles (see Figs 4d-e for their location) showing the changes in chemical composition during crystallization; $\mathbf{c}-\mathrm{Ti} / \mathrm{Al}$ ratio values (black crosses - profile a, gray crosses - profile b); $\mathbf{d}-\mathbf{e}-\mathrm{Back}-\mathrm{scatte}-$ red electron images of analysed clinopyroxene phenocryst with lines indicating the location of the two profiles. 

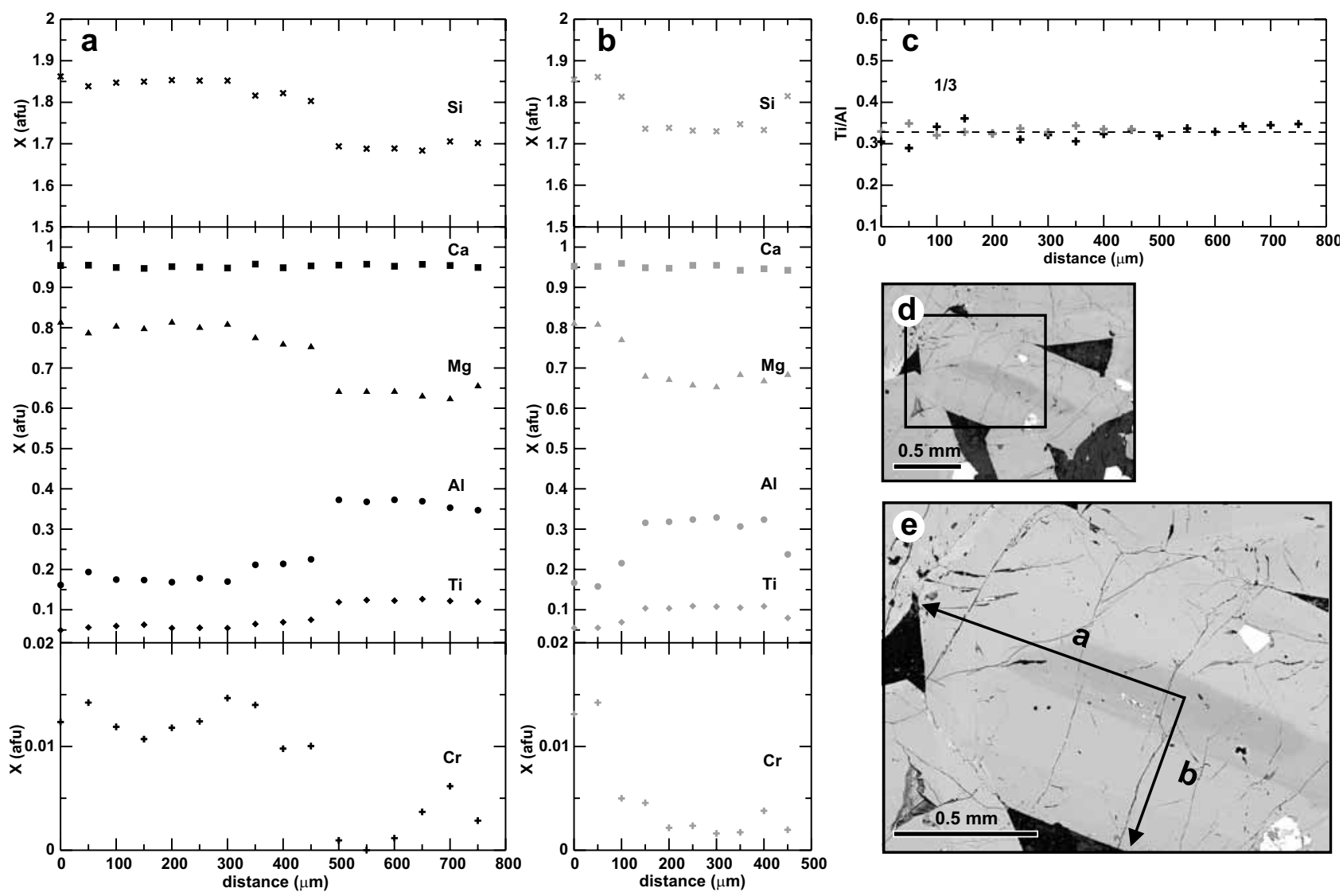

Fig. 5a-b Chemical variation of clinopyroxene from ijolite along two orthogonal profiles (see Figs $5 \mathrm{~d}-\mathrm{e}$ for their location) showing the changes in chemical composition during crystallization; $\mathbf{c}-\mathrm{Ti} / \mathrm{Al}$ ratio values (black crosses - profile a, gray crosses - profile b); $\mathbf{d}-\mathbf{e}-\mathrm{Back}-\mathrm{scattered}$ electron images of analysed clinopyroxene phenocryst with lines indicating the location of the two profiles.

is relatively insensitive to temperature, melt composition and oxygen fugacity, with a value of $0.3 \pm 0.03$. For calculation of the $\mathrm{Fo}_{\mathrm{eq}}$ content of olivine in equilibrium with bulk-rock mg\# the equation described by Roeder and Emslie (1970) was used.

The $\mathrm{Fo}_{\text {eq }}$ content of olivine in melteigite with the recalculated bulk-rock mg\# of 64.7 was calculated to be $\mathrm{Fo}_{\text {eq. } 86}$ (Tab. 2). This $\mathrm{Fo}_{\text {eq }}$ value is in good agreement with the highest measured Fo content in olivine $\left(\mathrm{Fo}_{85.5}\right)$ of this rock and supports the assumption that this mineral does not have a cumulate origin. Therefore, we used the recalculated melteigite major-element bulk-rock composition for crystallization sequence modelling using the PELE software (Boudreau 1999) based on the algorithms and database of Ghiorso (1985) and Ghiorso and Sack (1994).

The modelling started with calculated liquidus temperature of $1233^{\circ} \mathrm{C}$, pressure of $4 \mathrm{kbar}$, determined from clinopyroxene core compositions (see above), and an oxygen fugacity one log unit below the quartz-fayalitemagnetite (QFM) buffer. This oxygen fugacity value was determined according to the method of Buddington and Lindsley (1964). For the change of $f \mathrm{O}_{2}$ with temperature the model of Kress and Carmichael (1988) was used. Since the mineral assemblage is essentially anhydrous, we consider the melt to be relatively $\mathrm{H}_{2} \mathrm{O}$-poor, hence $\mathrm{H}_{2} \mathrm{O}$ was neglected in our calculations. The predicted crystallization sequence for equilibrium and fractional crystallization was compared with analysed chemical compositions of minerals. Thereafter, a final model of crystallization was computed in two steps. The first invoked early equilibrium crystallization of olivine and clinopyroxene cores, having simulated the presence of equilibrated Mg-rich cores of early-crystallized olivines and clinopyroxenes. The second step included fractional crystallization of residual liquid under a pressure of 0.2 $\mathrm{kbar}$ (assumed for the intrusion emplacement). The results of this crystallization model are shown in Fig. 6a-b.

\subsection{2 ljolite}

As in the case of the melteigite, the recalculated bulkrock composition (Tab. 2) was used for crystallization modelling of ijolite. However, the early-crystallized olivine is not present in this rock. Therefore we used the 
Tab. 2. Bulk-rock compositions used for crystallization modelling

\begin{tabular}{|c|c|c|c|c|}
\hline & \multicolumn{2}{|c|}{$\begin{array}{l}\text { real bulk-rock } \\
\text { compositions }\end{array}$} & \multicolumn{2}{|c|}{$\begin{array}{l}\text { modelled bulk-rock } \\
\text { compositions }\end{array}$} \\
\hline & melteigite & ijolite & melteigite & ijolite \\
\hline \multicolumn{5}{|l|}{ wt. \% } \\
\hline $\mathrm{SiO}_{2}$ & 40.74 & 38.05 & 41.38 & 39.16 \\
\hline $\mathrm{TiO}_{2}$ & 4.63 & 5.45 & 4.70 & 5.61 \\
\hline $\mathrm{Cr}_{2} \mathrm{O}_{3}$ & 0.06 & 0.01 & 0.06 & 0.01 \\
\hline $\mathrm{Al}_{2} \mathrm{O}_{3}$ & 9.57 & 10.71 & 9.72 & 11.02 \\
\hline $\mathrm{Fe}_{2} \mathrm{O}_{3}$ & 5.97 & 6.69 & 1.35 & 1.67 \\
\hline $\mathrm{FeO}$ & 6.62 & 6.85 & 10.92 & 11.73 \\
\hline $\mathrm{MnO}$ & 0.18 & 0.20 & 0.18 & 0.21 \\
\hline $\mathrm{MgO}$ & 11.06 & 8.28 & 11.23 & 8.52 \\
\hline $\mathrm{CaO}$ & 16.74 & 16.43 & 17.00 & 16.91 \\
\hline $\mathrm{Na}_{2} \mathrm{O}$ & 1.47 & 1.60 & 1.49 & 1.65 \\
\hline $\mathrm{K}_{2} \mathrm{O}$ & 1.24 & 1.57 & 1.26 & 1.62 \\
\hline $\mathrm{P}_{2} \mathrm{O}_{5}$ & 0.44 & 1.15 & 0.45 & 1.18 \\
\hline $\mathrm{F}$ & 0.13 & 0.18 & 0.13 & 0.18 \\
\hline $\mathrm{CO}_{2}$ & 0.10 & 0.50 & 0.10 & 0.51 \\
\hline $\mathrm{S}$ & 0.02 & 0.02 & 0.02 & 0.02 \\
\hline LOI & 0.77 & 1.53 & - & - \\
\hline Total & 99.73 & 99.22 & 100.00 & 100.00 \\
\hline $\mathrm{mg} \#$ & 62.2 & 53.4 & 64.7 & 56.4 \\
\hline $\mathrm{K}_{\mathrm{d}}$ & - & - & 0.3 & - \\
\hline $\mathrm{Fo}_{\mathrm{eq}}$ & - & - & 85.9 & - \\
\hline $\mathrm{T}_{\mathrm{Ol-liq}}\left({ }^{\circ} \mathrm{C}\right)$ & - & - & 1232 & - \\
\hline$(\mathrm{En}, \mathrm{Wo})_{\bmod }$ & - & - & - & $43.0,49.8$ \\
\hline $\mathrm{T}_{\mathrm{Cpx}-\mathrm{liq}}\left({ }^{\circ} \mathrm{C}\right)$ & - & - & - & 1123 \\
\hline $\log f \mathrm{O}_{2}$ & - & - & -11 & -11 \\
\hline
\end{tabular}

$\dagger$ Published analyses of Holub et al. (this volume).

Melteigite: sample DH1330, ijolite: sample DH1329.

₹ Recalculated bulk-rock compositions used for modelling

PELE software to calculate the chemical composition of the first clinopyroxene that could have crystallized from the modelled magma composition. The predicted clinopyroxene composition is $\mathrm{En}_{43}, \mathrm{Wo}_{50}$ (Tab. 2) and the highest $\mathrm{Mg}$-value measured from clinopyroxene core composition is $\mathrm{En}_{43.1}, \mathrm{Wo}_{49.5}$. This agreement was fundamental for crystallization modelling and suggests that the first clinopyroxene crystallized from the liquid was in equilibrium with the parental magma and that clinopyroxenes having this composition are not of cumulate origin.

The ijolite crystallization modelling started with calculated liquidus temperature of $1123{ }^{\circ} \mathrm{C}$, pressure of $0.2 \mathrm{kbar}$ (assumed emplacement pressure) and oxygen fugacity equivalent to one log unit below the quartz-fayalite-magnetite (QFM) buffer. The oxygen fugacity changes were treated as suggested by Kress and Carmichael (1988). When the models for fractional and equilibrium crystallization are compared, fractional crystallization yields a better agreement between the predicted and observed compositional ranges for studied mineral phases. The results of fractional crystallization modelling of ijolite are shown in Fig. 6c-d.

\subsection{Cooling rate estimation}

The chemical zoning preserved in olivine grains can be used to estimate cooling rate and thermal history of the given rock during its crystallization. The minimum cooling rates necessary for the preservation of measured compositional zoning in olivine grains of melteigite were determined following the kinetic model of Taylor et al. (1977) with interdiffusion coefficient for the $\mathrm{Mg}^{2+}$ and $\mathrm{Fe}^{2+}$ determined by Buening and Buseck (1973). The variations of Fo content in a selected olivine grain (Fig. 3), measured along mutually orthogonal profiles across the grain, were used to estimate the minimum cooling rates. The effects of crystallographic orientation (determined from EBSD analyses) on $\mathrm{Mg}-\mathrm{Fe}$ diffusion in the olivine grains were taken into account in the calculations. Based on the procedure of Taylor et al. (1977) the calculated minimal cooling rate of these olivine crystals is $\sim 0.02{ }^{\circ} \mathrm{C} / \mathrm{hr}$, or $175^{\circ} \mathrm{C} / \mathrm{yr}$.

\subsection{REE concentrations in clinopyroxenes}

Based on the large observed variations of major elements in the clinopyroxenes of melteigite and ijolite, the composition of REE in several clinopyroxene grains from both rocks was further investigated using the LA-ICP-MS (Tab. 3). The analyses of specific parts of the clinopyroxene grains were carried out to cover the wide range of clinopyroxene's major-element variation observed.

Rare earth element concentrations correlate with majorelement abundances (Fig. 7), whereby the cores of clinopyroxene grains (Cpx-1, Cpx-2 for both rocks, see Tab. 3) have consistently lower REE concentrations than the mantles (Cpx-3, Cpx-5 for melteigite and Cpx-3 for ijolite) and the rims (Cpx-4, Cpx-6 for melteigite and Cpx-4 for ijolite). Measured clinopyroxenes are clearly enriched in light REE (LREE) relative to heavy REE (HREE) without a Eu anomaly. Chondrite-normalized ratios $[\mathrm{La} / \mathrm{Lu}]_{\mathrm{n}}$ (normalization after Anders and Grevesse 1989) for studied melteigite clinopyroxenes vary in the range of 2.05-12.34 and for ijolite clinopyroxenes between 7.89 and 10.43.

\section{Discussion}

\subsection{Clinopyroxene composition as a record of crystallization processes}

During the crystallization of a basaltic magma, the Al/Ti ratios in clinopyroxene vary depending upon appearance and disappearance of other liquidus phases and changes in crystallization conditions. Thus, the co-variation between $\mathrm{Al}$ and $\mathrm{Ti}$ in clinopyroxene may provide useful information about the crystallization sequence. 
(a) melteigite equlibrium and fractional crystallization model

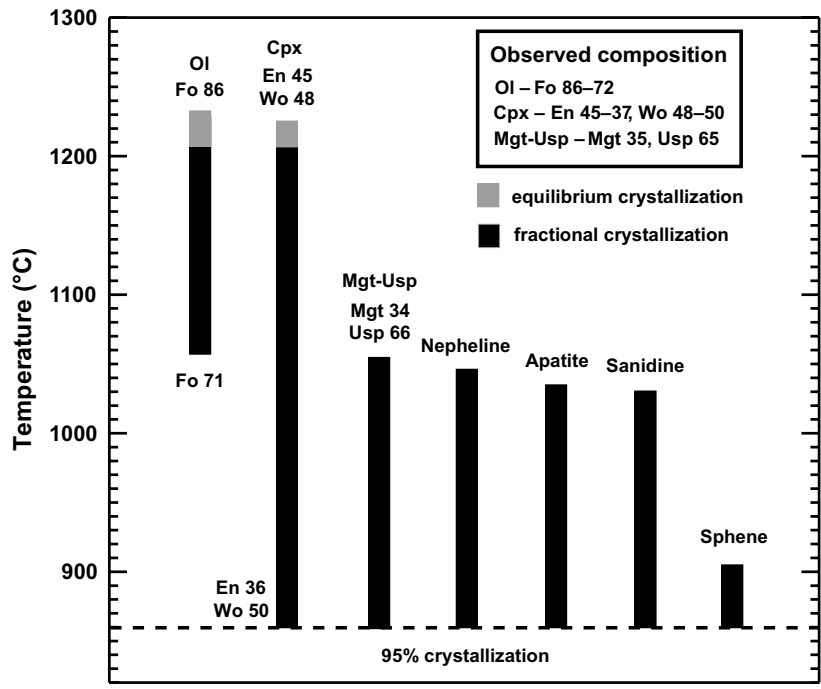

(b) melteigite equilibrium and fractional crystallization model

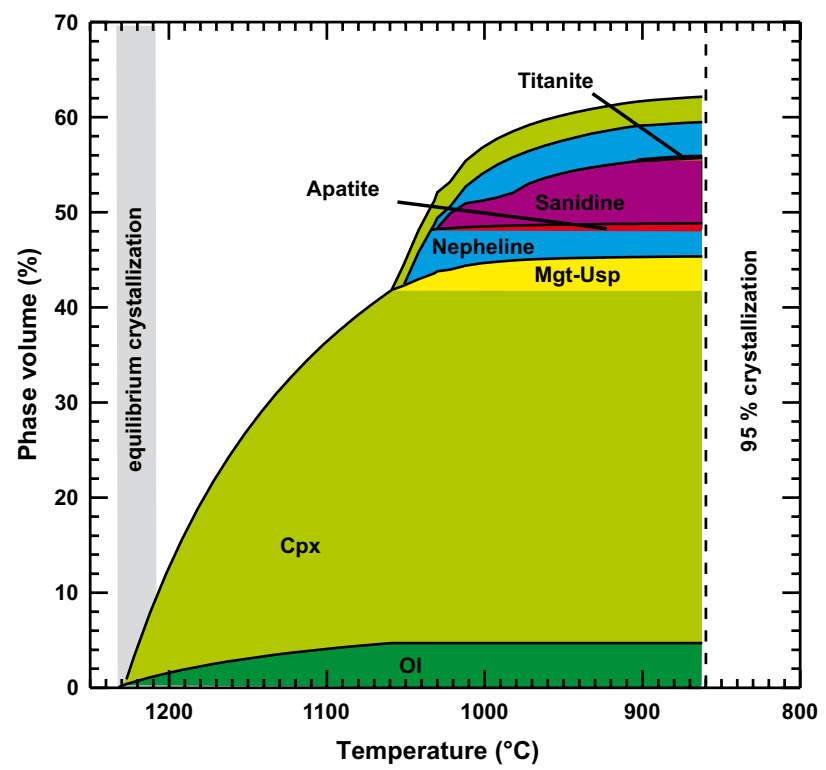

(c) ijolite fractional crystallization model

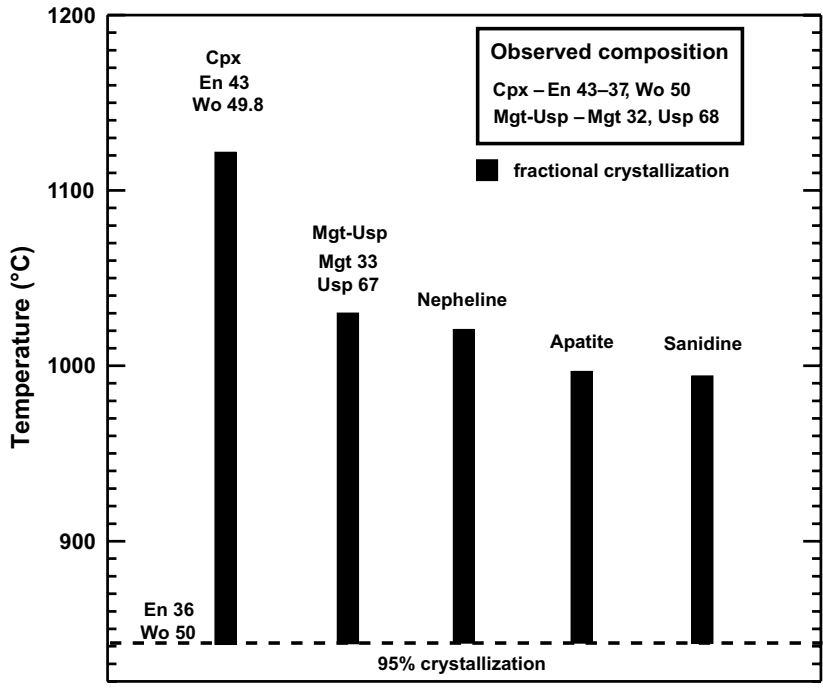

(d) ijolite fractional crystallization model

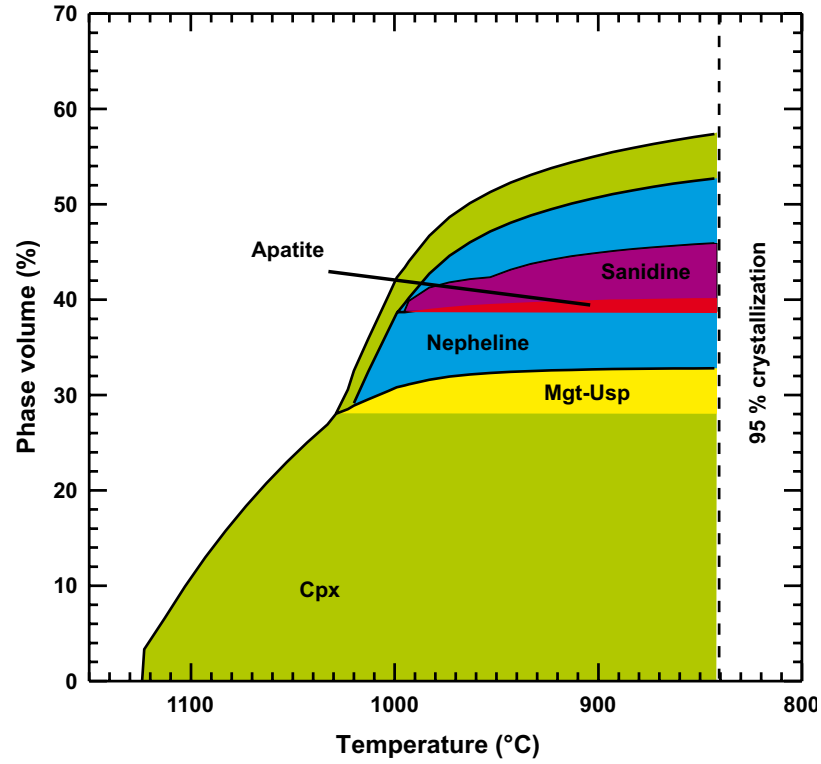

Fig. 6 Results of crystallization modelling of melteigite (a-b) and ijolite (c-d). Upper diagrams (a, c) in both cases show the modelled crystallization intervals of mineral phases with decreasing temperature and the ranges of their calculated/measured chemical compositions. Lower diagrams $(b, d)$ illustrate the modelled volumes of the crystallized phases appearing with the dropping temperature.

\subsubsection{Melteigite}

Magnesian cores of clinopyroxene grains are depleted in $\mathrm{Al}$ and high field-strength elements (HFSE) with $\Sigma(\mathrm{Al}$, $\mathrm{Ti}, \mathrm{Cr}) \approx 0.21 \mathrm{apfu}$ (based on 6 oxygens) relative to the mantles $(\Sigma(\mathrm{Al}, \mathrm{Ti}, \mathrm{Cr}) \approx 0.45)$ and $\operatorname{rims}(\Sigma(\mathrm{Al}, \mathrm{Ti}, \mathrm{Cr}) \approx$ 0.30 ) (Tabs 1, 3). The Ti/Al ratios in Mg-rich clinopyroxene cores are $\sim 0.2$ and reflect initial diopsidic Cpx crystallization (Fig. 4). Furthermore, these Mg-rich cores show only negligible variability in chemical composition. Clinopyroxene mantles enriched in $\mathrm{Ca}-\mathrm{Fe}-\mathrm{Al}-\mathrm{Ti}$ have higher concentrations of $\mathrm{Al}$ and $\mathrm{Ti}$ and lower $\mathrm{Si}$
(Tabs 1, 3 and Fig. 4). This trend suggests a combination of substitutions with overall stoichiometry $\mathrm{Fe}^{2+}+\mathrm{Ti}^{4+}+$ $2 \mathrm{Al}$ for $2 \mathrm{Mg}+2 \mathrm{Si}$, leading to the idealized end-member $\mathrm{CaFe}_{0.5} \mathrm{Ti}_{0.5} \mathrm{AlSiO}_{6}$. For crystallization of such Ti-Al-rich diopsides, the favourable conditions would be low pressure, high activity of $\mathrm{TiO}_{2}$ and low $f \mathrm{O}_{2}$ (Tracy and Robinson 1977). The change in $\mathrm{Ti} / \mathrm{Al}$ due to the substitution described above most probably indicates a rapid drop in pressure during magma rise to the final emplacement level. Subsequent decrease in $\mathrm{Ti}$ and $\mathrm{Fe}$ concentrations recorded in clinopyroxene (Fig. 4) can be interpreted as an appearance of Ti-rich magnetite on the liquidus, whereby 


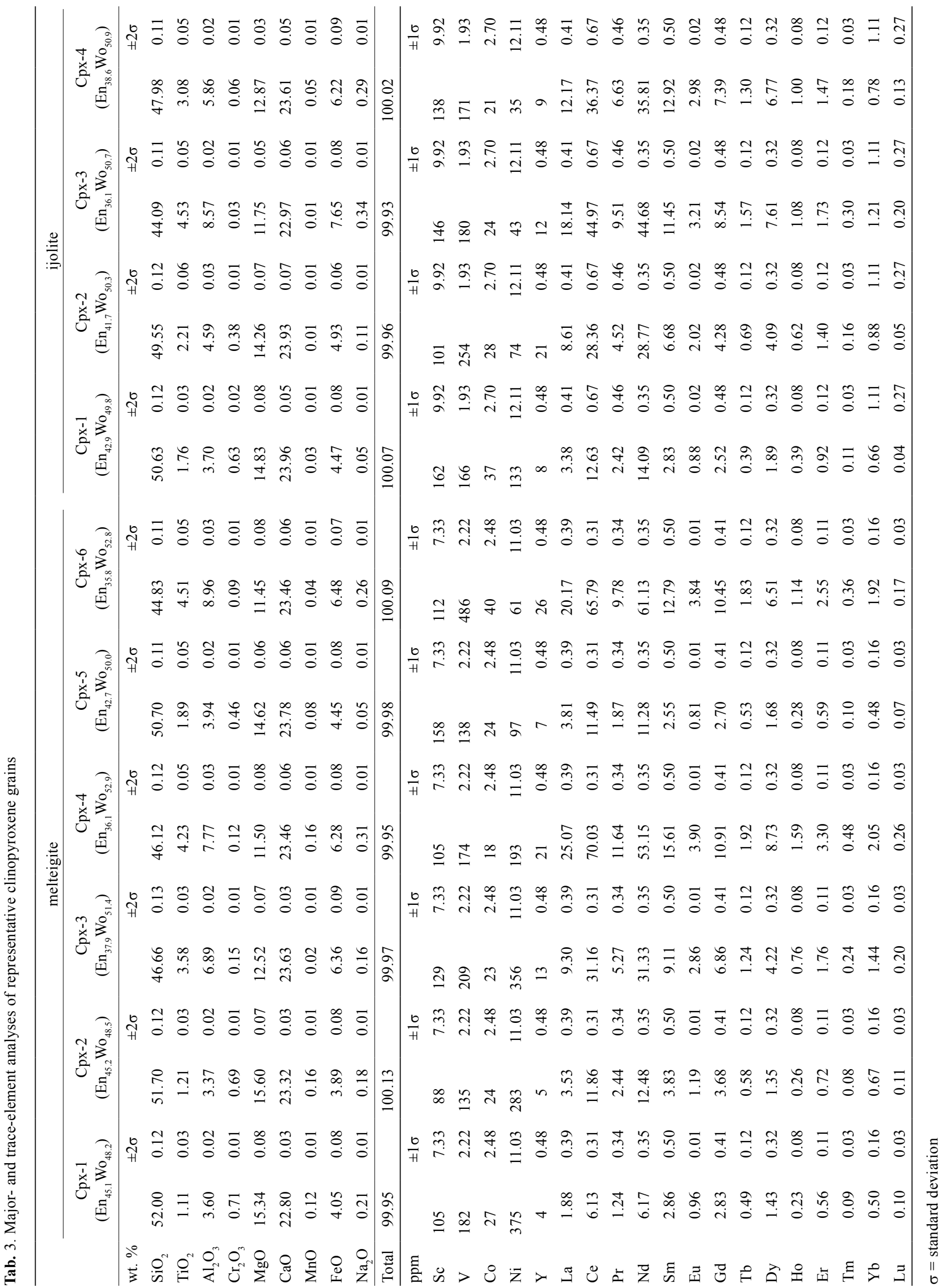



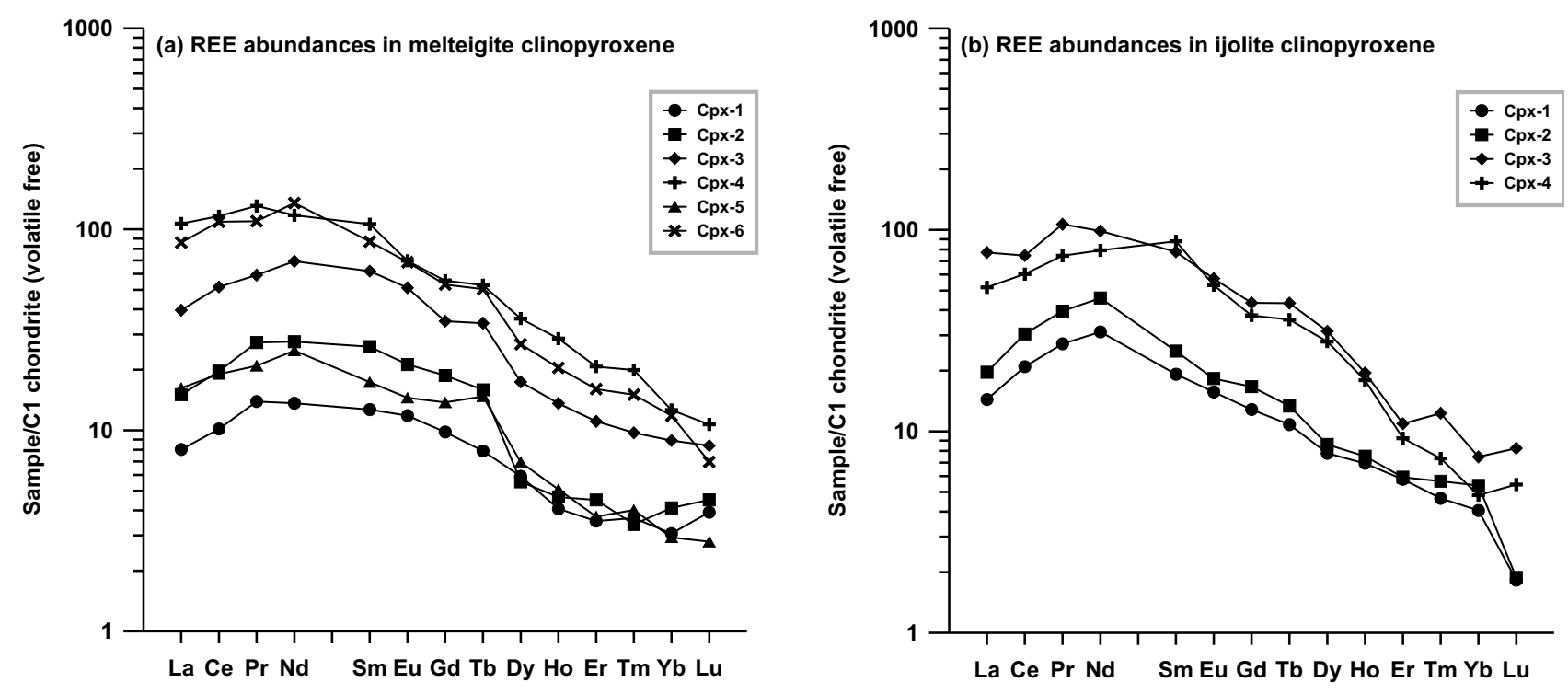

Fig. 7 The REE abundances in clinopyroxene from melteigite (a) and ijolite (b). Normalization values are from Anders and Grevesse (1989).

the amount of $\mathrm{Ti}$ and $\mathrm{Fe}$ uptake into the clinopyroxene structure would be controlled by the declining $\mathrm{Fe}$ and $\mathrm{Ti}$ contents in the melt. Also the simultaneous decrease of $\mathrm{Al}$ concentration in clinopyroxene (Fig. 4) indicates an onset of nepheline and sanidine crystallization. Thus, crystallization of magnetite together with nepheline, sanidine and clinopyroxene presumably lead to depletion in $\mathrm{Fe}, \mathrm{Ti}$ and $\mathrm{Al}$ in the residual magma as well as an increasing $\mathrm{Mg}$ uptake to the clinopyroxene structure.

Furthermore the concomitant decrease of $\mathrm{Al}, \mathrm{Ti}$ and $\mathrm{Fe}$ (see orthogonal profiles Fig. 4) indicate that magnetite, nepheline and sanidine begun to crystallize probably at the same time during crystallization of clinopyroxene. The melteigite crystallization sequence of major mineral phases, derived from variations in $\mathrm{Ti}$ and $\mathrm{Al}$ contents and clinopyroxene chemical zoning, can be proposed as follows: $\mathrm{Ol} \rightarrow \mathrm{Ol}+\mathrm{Cpx} \rightarrow \mathrm{Cpx}+\mathrm{Mgt} \rightarrow \mathrm{Cpx}+\mathrm{Mgt}+\mathrm{Ne}$ $\rightarrow \mathrm{Cpx}+\mathrm{Mgt}+\mathrm{Ne}+\mathrm{Sa}$. Coexisting magnetite-ilmenite pairs indicate $\log f \mathrm{O}_{2}=-11$, calculated using the method of Buddington and Lindsley (1964). This is slightly more reducing than the quartz-fayalite-magnetite buffer.

\subsubsection{Ijolite}

Similarly to the melteigite, the Mg-rich cores of clinopyroxene grains are also depleted in Al and HFSE with $\Sigma(\mathrm{Al}, \mathrm{Ti}, \mathrm{Cr}) \approx 0.25$ apfu (based on 6 oxygens) relative to the mantles $(\Sigma(\mathrm{Al}, \mathrm{Ti}, \mathrm{Cr}) \approx 0.51)$ and the rims $(\Sigma(\mathrm{Al}, \mathrm{Ti}$, $\mathrm{Cr}) \approx 0.35)($ Tabs 1,3$)$. This indicates that the clinopyroxenes of ijolites are more enriched in the HFSE than those of melteigites. Furthermore the Ti/Al ratio is the same for $\mathrm{Mg}$-rich cores and mantles enriched in $\mathrm{Ca}, \mathrm{Fe}, \mathrm{Al}$, and
Ti, having a consistent value of 0.33 (Fig. 5). This fact documents that ijolite clinopyroxene crystallized from a more fractionated magma that was enriched in $\mathrm{Al}$ and $\mathrm{Ti}$ in respect to the melteigite. This assumption is also supported by the bulk-rock composition, lower mg\# (Tab. 2) and absence of strongly $\mathrm{Mg}$-enriched clinopyroxene cores with low abundances of $\mathrm{Al}$ and Ti. The uniform Ti/Al values for $\mathrm{Mg}$-rich cores and $\mathrm{Ca}, \mathrm{Fe}, \mathrm{Al}$, Ti-rich mantles also indicate substitution of $\mathrm{Fe}^{2+}+\mathrm{Ti}^{4+}+2 \mathrm{Al}$ for $2 \mathrm{Mg}$ $+2 \mathrm{Si}$ during the whole crystallization interval of the parental magma that led to a significant enrichment of $\mathrm{Al}$ and Ti, especially in clinopyroxene mantles. This observation is consistent with clinopyroxene crystallization from magma enriched in $\mathrm{Al}$ and $\mathrm{Ti}$ under lower pressure, i.e. at its final emplacement level.

A subsequent decrease in $\mathrm{Ti}$ and $\mathrm{Fe}$ concentrations recorded in clinopyroxene rims (Fig. 5) can be interpreted (identically to the case of melteigite) as an appearance of Ti-rich magnetite on the liquidus, when the amount of $\mathrm{Ti}$ and Fe uptake into the crystal structure was affected by simultaneous crystallization of Ti-rich magnetite. Furthermore, concomitant decrease in clinopyroxene Al contents (Fig. 5) indicates the onset of nepheline and sanidine crystallization. Crystallization of magnetite together with nepheline, sanidine and clinopyroxene presumably led to the Fe, Ti and $\mathrm{Al}$ depletion of the residual melt.

The crystallization sequence of major mineral phases, derived from $\mathrm{Ti} / \mathrm{Al}$ values and clinopyroxene chemical zoning, is: $\mathrm{Cpx} \rightarrow \mathrm{Cpx}+\mathrm{Mgt} \rightarrow \mathrm{Cpx}+\mathrm{Mgt}+\mathrm{Ne} \rightarrow \mathrm{Cpx}$ $+\mathrm{Mgt}+\mathrm{Ne}+\mathrm{Sa}$. This crystallization sequence is in good agreement with the results of crystallization modelling (see section 5.2.2.). 


\subsection{Crystallization modelling}

\subsubsection{Melteigite}

Numerical modelling can provide significant information for understanding the crystallization processes of the studied melteigite. When the resulting two-step model is compared with mineral chemistry data, the model yields a very good fit between predicted and observed compositional ranges for both olivine and clinopyroxene (Fig. 6). The first step of the model is equilibrium crystallization for the recalculated bulk composition of melteigite at 4 kbar (Tab. 2, Fig. 6) predicting the olivine $\left(\mathrm{Fo}_{86}\right)$ as a first phase to crystallize from the cooling liquid at $1232{ }^{\circ} \mathrm{C}$, followed by diopsidic pyroxene $\left(\mathrm{En}_{45}, \mathrm{Wo}_{48}\right)$ at $1227^{\circ} \mathrm{C}$. This first crystallization phase finished at $1209{ }^{\circ} \mathrm{C}$ (olivine $\mathrm{Fo}_{85}+$ clinopyroxene $\mathrm{En}_{44}, \mathrm{Wo}_{48}$ ). The modelled olivine and clinopyroxene compositions correspond to the compositional variation in our samples (see above and Fig. 4).

The second step is assumed to have taken place at a pressure of $0.2 \mathrm{kbar}$. The fractional crystallization model infers crystallization of olivine $\left(\mathrm{Fo}_{85}\right)$ and clinopyroxene $\left(\mathrm{En}_{41}, \mathrm{Wo}_{50}\right)$. The end of olivine crystallization $\left(\mathrm{Fo}_{71}\right)$ predicted at $1058{ }^{\circ} \mathrm{C}$ was followed by crystallization of ulvöspinel $\left(\mathrm{Mgt}_{34}, \mathrm{Usp}_{66}\right)$ at $1057^{\circ} \mathrm{C}$, nepheline at $1047^{\circ} \mathrm{C}$, apatite at $1035^{\circ} \mathrm{C}$, sanidine at $1030{ }^{\circ} \mathrm{C}$ and titanite at $905{ }^{\circ} \mathrm{C}$.

The predicted and observed mineral chemistries are in good mutual agreement (Fig. 6). The sudden drop in pressure and onset of substitution of $\mathrm{Fe}^{2+}+\mathrm{Ti}^{4+}+2 \mathrm{Al}$ for $2 \mathrm{Mg}+2 \mathrm{Si}$ in clinopyroxene explain the predicted and observed compositional gap in the clinopyroxene (Fig. 4). The two-step crystallization model is consistent with the crystallization sequence derived from $\mathrm{Ti} / \mathrm{Al}$ variations in clinopyroxenes (section 5.1.1 and Fig. 4) and provides us with a very detailed insight into the crystallization evolution of melteigite from the parental magma. The melteigite crystallization model also excludes the presence of accumulated minerals and, together with other lines of evidence (e.g., type of chemical zoning of olivine and clinopyroxene - section 4.1.1; strong REE variations between core and rim for clinopyroxene grains - section 4.4 ), reflects the role of fractional crystallization processes during crystallization of the magma.

\subsubsection{Ijolite}

When we compare the results of fractional crystallization modelling of the studied ijolite at a pressure of $0.2 \mathrm{kbar}$, the very good fit between predicted and observed chemical compositions of main mineral phases is apparent (Figs 5-6). Diopsidic pyroxene $\left(\mathrm{En}_{43}, \mathrm{Wo}_{50}\right)$ is the first phase that was modelled to have crystallized from the cool- ing parental magma at $1123{ }^{\circ} \mathrm{C}$ followed by ulvöspinel $\left(\mathrm{Mgt}_{32}, \mathrm{Usp}_{68}\right)$ at $1029{ }^{\circ} \mathrm{C}$, nepheline at $1020{ }^{\circ} \mathrm{C}$, apatite at $999{ }^{\circ} \mathrm{C}$ and sanidine at $995^{\circ} \mathrm{C}$. Similarly to the melteigite, the agreement between the predicted and observed compositions of the early-crystallized clinopyroxene excludes any significant presence of accumulated minerals. The predicted limited temperature range of the beginning of Ti-rich magnetite, nepheline, apatite and sanidine crystallization corresponds well with the chemical record in pyroxene. The $\mathrm{Fe}^{2+}+\mathrm{Ti}^{4+}+2 \mathrm{Al}$ for $2 \mathrm{Mg}+2 \mathrm{Si}$ substitution was already significant in the clinopyroxene core, confirming that low-pressure fractional crystallization was effective throughout the whole crystallization interval. The results of crystallization modelling for both studied rocks suggest that, after final emplacement of parental magmas, they crystallized under similar conditions. However, the chemical compositions of these parental magmas were slightly different (Tab. 2). The melteigite model, together with the observed chemical composition of the clinopyroxene, records also an early equilibrium crystallization history of olivine and clinopyroxene at higher pressure, whereas the slightly more fractionated ijolite magma crystallized entirely at a lower pressure.

\subsection{Character of the parental magmas}

\subsubsection{Melteigite}

The rare-earth element concentrations of melteigite clinopyroxenes measured by LA-ICP-MS show significant variations (Fig. 7a) suggesting an extensive fractionalcrystallization history of the melteigite magma. The REE compositions of clinopyroxene can be therefore used to estimate the composition of the liquid with which they were in equilibrium at the time of crystallization (e.g., McSween et al. 1996). As shown by these authors, good agreement between bulk-rock and estimated equilibrium melt REE contents for the earliest-formed minerals could indicate evolution of the parental magma in a closedsystem. On the other hand, it is also possible to detect the presence of minerals with cumulitic origin or potential escape of some REE-enriched residual melt expelled by the filter-pressing processes.

The studied clinopyroxenes have in their Mg-rich cores lower REE abundances than their $\mathrm{Ca}-\mathrm{Fe}-\mathrm{Al}-\mathrm{Ti}$ rich mantles and $\mathrm{Ca}-\mathrm{Mg}$-rich rims. The correlation of $(\mathrm{La} / \mathrm{Lu})_{\mathrm{n}}$ values with the Wo and En contents is illustrated in Fig. 8. In general, the $(\mathrm{La} / \mathrm{Lu})_{\mathrm{n}}$ values of Mg-rich cores are lower than those of mantles and rims. This observation can easily be explained as an increase in $(\mathrm{La} / \mathrm{Lu})_{\mathrm{n}}$ value with progressive magma fractionation. The lowest $(\mathrm{La} / \mathrm{Lu})_{\mathrm{n}}$ values seen in equilibrated Mg-rich cores (Fig. $8 \mathrm{a}-\mathrm{b})$ are in agreement with petrographic observations and numerical modelling, suggesting that this was the 

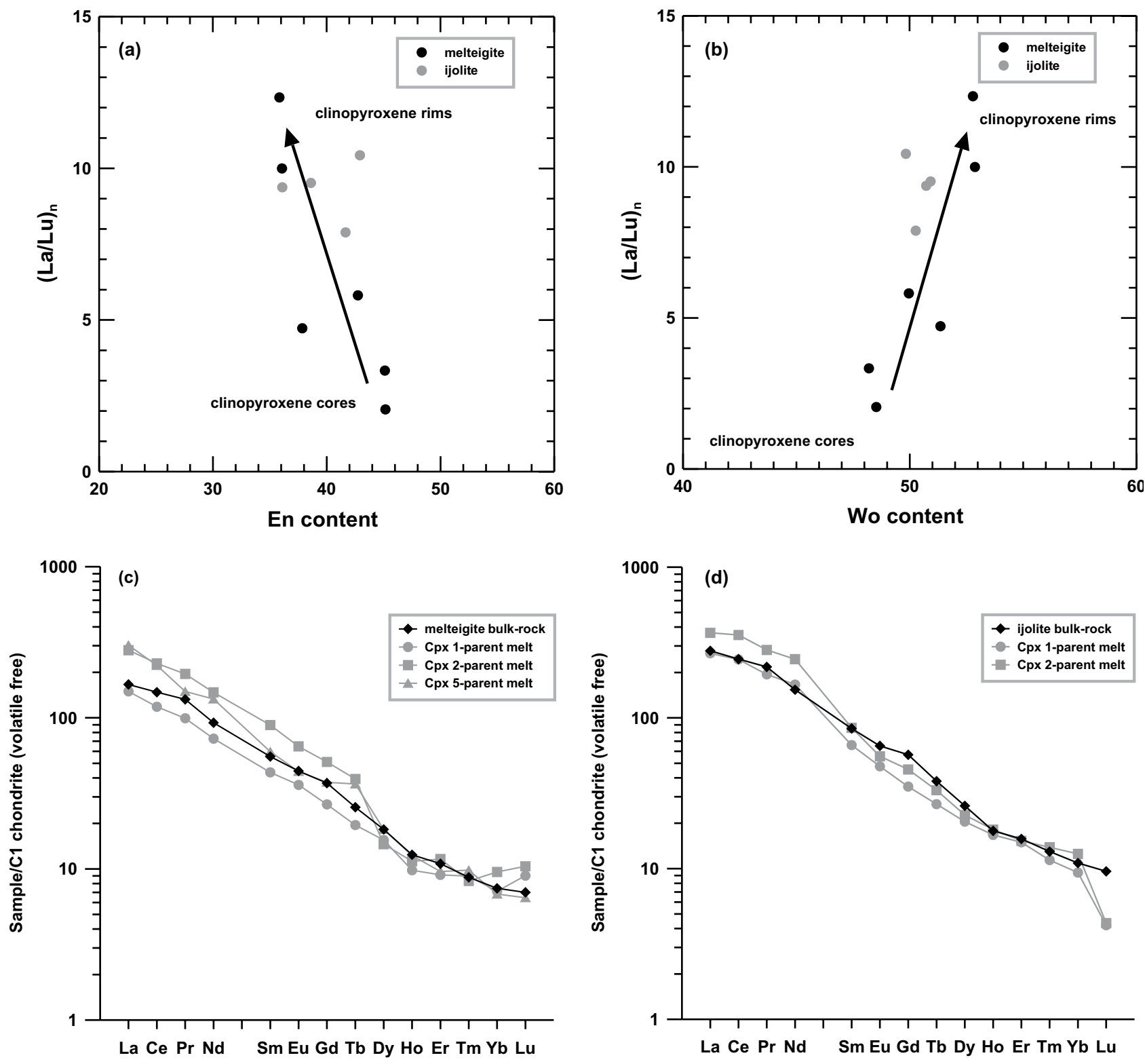

Fig. 8a-b - Correlation plots between $(\mathrm{La} / \mathrm{Lu})_{n}$ and En and Wo contents in analysed clinopyroxenes; $\mathbf{c}-\mathbf{d}$ Modelled REE abundances in melts parental to melteigite (c) and ijolite (d). Normalization values are from Anders and Grevesse (1989).

earliest clinopyroxene crystallizing from the melteigite parental magma.

In estimating the composition of the melteigite parental magma, REE partition coefficients between olivine and melt, published by Bédard (2005), appear to be too low. In our evaluation we therefore take into account the bulk-rock REE concentrations (Tab. 3.) published by Holub et al. (this volume), and the olivine modal abundance in this rock. The REE abundances in measured olivine grains are very low, often below the detection limit of LA-ICP-MS. In any case, this mineral could accommodate only $<0.01 \mathrm{ppm}$ of total REE and was therefore excluded from the calculation.

The equilibrium melt compositions have thus been calculated for the earliest formed Mg-rich diopsidic pyroxene having the lowest REE concentrations and consuming substantial amounts of REE from the parental magma (Cpx-1, Cpx-2, see Tab. 3 and Fig. 7a). The REE partition coefficients between diopsidic clinopyroxene and melt of Hart and Dunn (1993) were used. In addition, melt compositions in equilibrium with the $\mathrm{Ca}, \mathrm{Fe}$, $\mathrm{Al}$ and Ti-rich clinopyroxene ( $\mathrm{Cpx}-5)$ with the highest 
Tab. 4. The measured bulk-rock REE compositions and calculated equilibrium melt REE compositions for melteigite and ijolite

\begin{tabular}{|c|c|c|c|c|c|c|c|c|c|c|c|c|}
\hline \multirow{2}{*}{ REE (ppm) } & \multirow{2}{*}{$\mathrm{D}_{\mathrm{Cpx}}$} & \multirow{2}{*}{$\begin{array}{l}\text { melteigite } \\
\text { bulk-rock }\end{array}$} & \multirow{2}{*}{$\begin{array}{l}\text { (melteigite } \\
\text { bulk-rock) }\end{array}$} & \multicolumn{9}{|c|}{ melteigite earliest formed pyroxenes } \\
\hline & & & & Cpx-1 & Cpx-1-pm & $(\mathrm{Cpx}-1-\mathrm{pm})_{\mathrm{n}}$ & Cpx-2 & Cpx-2-pm & $(\mathrm{Cpx}-2-\mathrm{pm})_{\mathrm{n}}$ & Cpx-5 & Cpx-5-pm & $(\mathrm{Cpx}-5-\mathrm{pm})_{\mathrm{n}}$ \\
\hline $\mathrm{La}$ & 0.054 & 39.00 & 166.17 & 1.88 & 35.13 & 149.67 & 3.53 & 65.79 & 280.30 & 3.81 & 71.02 & 302.58 \\
\hline $\mathrm{Ce}$ & 0.086 & 89.10 & 147.71 & 6.13 & 71.40 & 118.37 & 11.86 & 138.28 & 229.24 & 11.49 & 133.91 & 222.00 \\
\hline $\operatorname{Pr}$ & 0.140 & 11.80 & 132.44 & 1.24 & 8.85 & 99.32 & 2.44 & 17.40 & 195.26 & 1.87 & 13.32 & 149.53 \\
\hline $\mathrm{Nd}$ & 0.187 & 42.00 & 92.84 & 6.17 & 32.92 & 72.76 & 12.48 & 66.66 & 147.34 & 11.28 & 60.21 & 133.09 \\
\hline $\mathrm{Sm}$ & 0.291 & 8.15 & 55.40 & 1.86 & 6.41 & 43.56 & 3.83 & 13.17 & 89.56 & 2.55 & 8.78 & 59.67 \\
\hline $\mathrm{Eu}$ & 0.329 & 2.49 & 44.46 & 0.66 & 2.01 & 35.97 & 1.19 & 3.62 & 64.63 & 0.81 & 2.47 & 44.11 \\
\hline $\mathrm{Gd}$ & 0.367 & 7.27 & 36.98 & 1.93 & 5.25 & 26.72 & 3.68 & 10.03 & 51.02 & 2.70 & 7.37 & 37.46 \\
\hline $\mathrm{Tb}$ & 0.404 & 0.93 & 25.62 & 0.29 & 0.71 & 19.52 & 0.58 & 1.43 & 39.38 & 0.53 & 1.32 & 36.48 \\
\hline Dy & 0.380 & 4.43 & 18.25 & 1.43 & 3.77 & 15.54 & 1.35 & 3.54 & 14.59 & 1.68 & 4.43 & 18.23 \\
\hline Ho & 0.415 & 0.69 & 12.41 & 0.23 & 0.55 & 9.81 & 0.26 & 0.62 & 11.24 & 0.28 & 0.68 & 12.26 \\
\hline Er & 0.387 & 1.72 & 10.82 & 0.56 & 1.45 & 9.13 & 0.72 & 1.85 & 11.63 & 0.59 & 1.53 & 9.61 \\
\hline $\mathrm{Tm}$ & 0.409 & 0.21 & 8.80 & 0.09 & 0.22 & 8.96 & 0.08 & 0.20 & 8.33 & 0.10 & 0.24 & 9.82 \\
\hline $\mathrm{Yb}$ & 0.430 & 1.21 & 7.45 & 0.50 & 1.16 & 7.12 & 0.67 & 1.55 & 9.55 & 0.48 & 1.11 & 6.82 \\
\hline $\mathrm{Lu}$ & 0.433 & 0.17 & 7.00 & 0.10 & 0.22 & 9.03 & 0.11 & 0.25 & 10.41 & 0.07 & 0.16 & 6.44 \\
\hline \multirow{2}{*}{ REE (ppm) } & \multirow{2}{*}{$\mathrm{D}_{\mathrm{Cpx}}$} & \multirow{2}{*}{$\begin{array}{c}\text { ijolite } \\
\text { bulk-rock }\end{array}$} & \multirow{2}{*}{$\begin{array}{c}\text { (ijolite } \\
\text { bulk-rock) }\end{array}$} & \multicolumn{6}{|c|}{ ijolite earliest formed pyroxene } & & & \\
\hline & & & & $\mathrm{Cpx}-1$ & Cpx-1-pm & $(\mathrm{Cpx}-1-\mathrm{pm})_{\mathrm{n}}$ & $\mathrm{Cpx}-2$ & Cpx-2-pm & $(\mathrm{Cpx}-2-\mathrm{pm})_{\mathrm{n}}$ & & & \\
\hline $\mathrm{La}$ & 0.054 & 65.40 & 278.65 & 3.38 & 62.97 & 268.32 & 4.61 & 86.03 & 366.53 & & & \\
\hline $\mathrm{Ce}$ & 0.086 & 148.00 & 245.36 & 12.63 & 147.21 & 244.04 & 18.36 & 213.93 & 354.66 & & & \\
\hline $\operatorname{Pr}$ & 0.140 & 19.40 & 217.73 & 2.42 & 17.31 & 194.29 & 3.52 & 25.17 & 282.51 & & & \\
\hline $\mathrm{Nd}$ & 0.187 & 69.50 & 153.63 & 14.09 & 75.21 & 166.25 & 20.77 & 110.89 & 245.12 & & & \\
\hline $\mathrm{Sm}$ & 0.291 & 12.50 & 84.98 & 2.83 & 9.71 & 66.00 & 3.68 & 12.63 & 85.89 & & & \\
\hline $\mathrm{Eu}$ & 0.329 & 3.65 & 65.18 & 0.88 & 2.67 & 47.69 & 1.02 & 3.11 & 55.60 & & & \\
\hline $\mathrm{Gd}$ & 0.367 & 11.20 & 56.97 & 2.52 & 6.88 & 34.99 & 3.28 & 8.94 & 45.45 & & & \\
\hline $\mathrm{Tb}$ & 0.404 & 1.38 & 38.02 & 0.39 & 0.97 & 26.75 & 0.49 & 1.20 & 33.10 & & & \\
\hline Dy & 0.380 & 6.33 & 26.08 & 1.89 & 4.97 & 20.49 & 2.09 & 5.50 & 22.66 & & & \\
\hline Ho & 0.415 & 0.99 & 17.81 & 0.39 & 0.93 & 16.73 & 0.42 & 1.01 & 18.15 & & & \\
\hline Er & 0.387 & 2.50 & 15.73 & 0.92 & 2.37 & 14.94 & 0.94 & 2.43 & 15.29 & & & \\
\hline $\mathrm{Tm}$ & 0.409 & 0.31 & 12.98 & 0.11 & 0.28 & 11.39 & 0.14 & 0.34 & 13.85 & & & \\
\hline $\mathrm{Yb}$ & 0.430 & 1.77 & 10.89 & 0.66 & 1.53 & 9.40 & 0.88 & 2.04 & 12.53 & & & \\
\hline $\mathrm{Lu}$ & 0.433 & 0.23 & 9.59 & 0.04 & 0.10 & 4.21 & 0.05 & 0.11 & 4.35 & & & \\
\hline
\end{tabular}

REE mineral-melt partition coefficients for diopsidic clinopyroxene (D) (Hart and Dunn 1993), REE concentrations and normalized REE concentrations in melteigite (DH1330) and ijolite (DH1329) adopted from Holub et al. (this volume), measured REE concentrations in Mg-rich clinopyroxene, calculated REE concentrations for parental melts in equilibrium (X-pm) and calculated normalized REE concentrations for parental melt in equilibrium $(\mathrm{Xpm})_{\mathrm{n}}$. Normalization values are from Anders and Grevesse (1989).

En component (and with the lowest REE concentrations) have also been calculated in this model. The calculated equilibrium melt REE compositions are compared with measured bulk-rock REE contents (Holub et al. this volume) in Tab. 4 and Fig. 8c.

The bulk-rock REE concentrations of melteigite are very similar to the calculated equilibrium melt REE concentrations for Mg-rich diopsidic pyroxene (Cpx-1, Cpx-2, see Tab. 4, Fig. 8c). Furthermore, the REE composition of melts in equilibrium with early-formed diopsidic pyroxene and $\mathrm{Ca}, \mathrm{Fe}, \mathrm{Al}$ and Ti-rich clinopyroxene with the highest En component (Cpx-5), are also similar to each other, suggesting that both clinopyroxenes crystallized from similar melts. This calculation is consistent 
with the results of crystallization modelling (see section 4.2.1) predicting the early equilibrium crystallization of olivine and $\mathrm{Mg}$-rich diopsidic pyroxene and subsequent fractional crystallization of clinopyroxene enriched in $\mathrm{Ca}, \mathrm{Fe}, \mathrm{Al}$ and $\mathrm{Ti}$.

The similarity between the measured bulk-rock and calculated equilibrium melt REE contents supports the assumption that the REE composition of the melteigite reflects that of the parental melt very well. This fact, together with the outcome of crystallization modelling, excludes the presence of any significant cumulate olivine/ clinopyroxene or removal of REE-enriched residual melt. The results of the parental magma composition modelling thus indicate a closed-system crystallization of the melteigite parental magma.

\subsubsection{Ijolite}

The REE concentrations in ijolite clinopyroxenes measured by LA-ICP-MS showed also significant variations (Tab. 3, Fig. 7b). These clinopyroxenes have lower REE abundances in their Mg-rich cores than in their mantles and rims. The correlation of $(\mathrm{La} / \mathrm{Lu})_{\mathrm{n}}$ values with the Wo and En contents of clinopyroxenes also demonstrates an increasing degree of magma fractionation (Fig. 8a-b). However, the range of $(\mathrm{La} / \mathrm{Lu})_{\mathrm{n}}$ is in this case much more limited compared to that in the melteigite clinopyroxenes. This observation, together with the results of crystallization modelling and the chemical composition recorded in clinopyroxenes, reflects a generally simple low-P fractional crystallization history. Furthermore, the evolution of the ijolite magma implies also variations in REE between clinopyroxene cores, mantles and rims (Fig. 7b). The results of crystallization modelling suggest that the clinopyroxene with the highest En content should be the earliest phase to have crystallized from the parental magma. The REE contents of these clinopyroxenes were therefore used for the estimates of the parental liquid composition using the same method as applied to the melteigite clinopyroxene.

Good agreement between the observed bulk-rock and the estimated equilibrium melt REE compositions for the earliest formed clinopyroxenes once again indicates that these pyroxenes crystallized from magma with a composition resembling that of the bulk rock (Tab. 4, Fig. 8d). Moreover, this also indicates a closed-system fractional crystallization.

\subsection{Genetic relationship between melteigite and ijolite}

The results of crystallization modelling and REE parental melts composition estimations suggest the possibility of a close petrogenetic relationship between both studied ijolitic rocks from the Flurbühl Composite Intrusion. For verification of this theory we used the modelled bulk-rock melteigite composition (Tab. 2) as that of initial melt. Taking into account modal abundances of early crystallized olivine and clinopyroxene that originated during the equilibrium phase of crystallization (see section 5.1.1) and their chemical composition, 4 wt. \% olivine and $10 \mathrm{wt}$. \% clinopyroxene were removed, and the bulk composition of melteigite was recalculated (Tab. 5). After this first step, the recalculated bulk-rock composition was far from the fractionated ijolite bulk rock composition (Tab. 5, Fig. 9), thus indicating that the ijolite bulk-rock

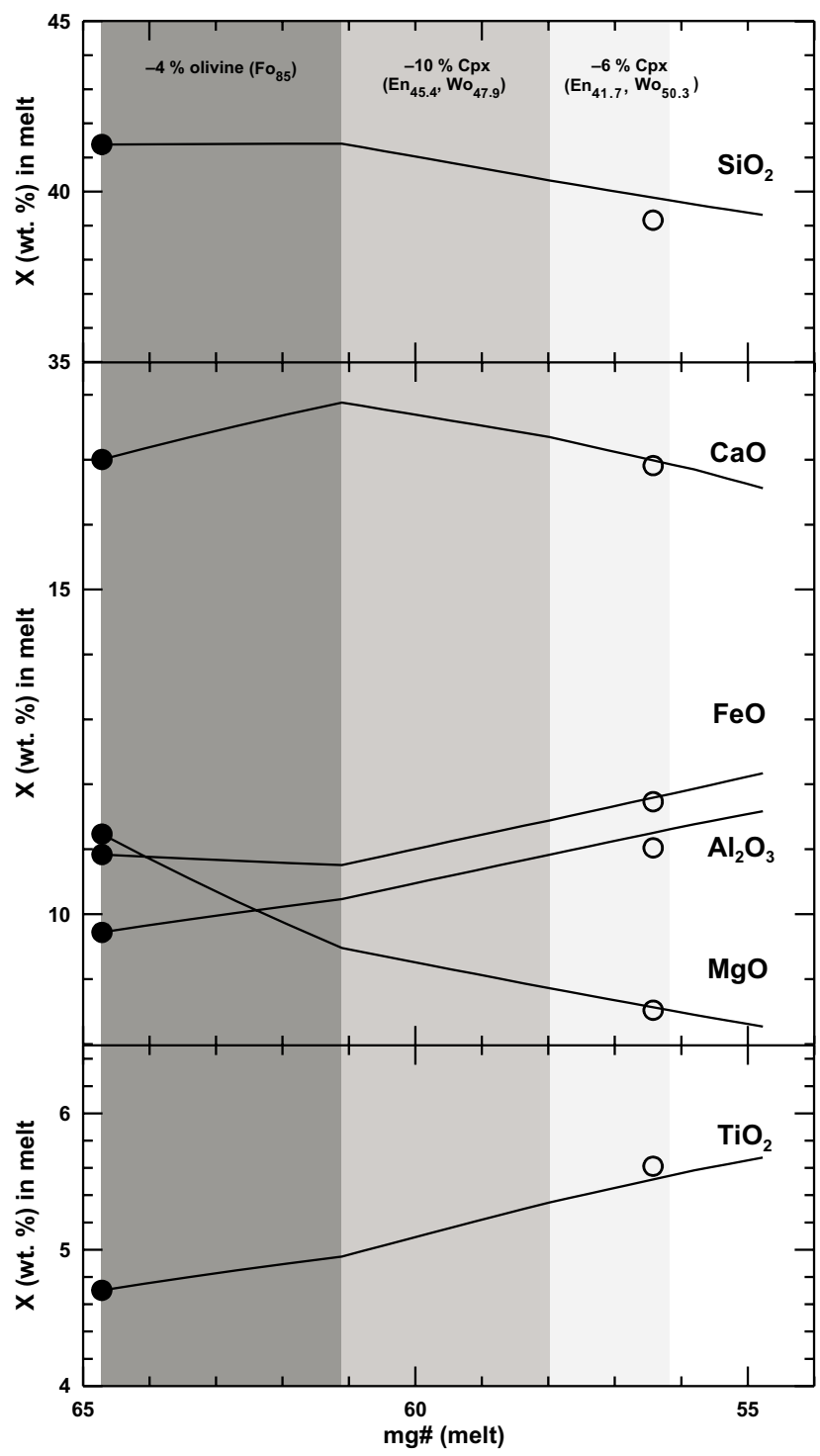

Fig. 9 Modelled evolution of $\mathrm{SiO}_{2}, \mathrm{CaO}, \mathrm{FeO}, \mathrm{Al}_{2} \mathrm{O}_{3}, \mathrm{MgO}$ and $\mathrm{TiO}_{2}$ contents in the melt after removal of $4 \% \mathrm{Ol}, 10 \% \mathrm{Cpx}$ and $6 \% \mathrm{Cpx}$ with the indicated chemical compositions. The initial chemistry of the melt (black dots) represents the recalculated melteigite bulk-rock composition. Recalculated real bulk-rock composition of ijolite (circles) is also plotted. 
Tab. 5. Recalculated and modelled melteigite and ijolite bulk-rock compositions

\begin{tabular}{|c|c|c|c|c|c|c|c|}
\hline & $\begin{array}{c}\text { melteigite } \\
\text { (recalculated } \\
\text { bulk-rock } \\
\text { composition) }\end{array}$ & $\begin{array}{c}\text { 1. step } \\
\text { melteigite } \\
(-4 \% \mathrm{Ol}, \\
-10 \% \mathrm{Cpx})\end{array}$ & $\begin{array}{c}\text { 2. step } \\
\text { melteigite } \\
(-6 \% \mathrm{Cpx})\end{array}$ & $\begin{array}{c}\text { ijolite } \\
\text { (recalculated } \\
\text { bulk-rock } \\
\text { composition) }\end{array}$ & $\begin{array}{c}\text { 1. step } \\
\text { Ol composition }\end{array}$ & $\begin{array}{c}\text { 1. step } \\
\text { Cpx composition }\end{array}$ & $\begin{array}{c}\text { 2. step } \\
\text { Cpx composition }\end{array}$ \\
\hline \multicolumn{8}{|l|}{ wt. $\%$} \\
\hline $\mathrm{SiO}_{2}$ & 41.41 & 40.33 & 39.73 & 39.16 & 40.88 & 52.08 & 49.73 \\
\hline $\mathrm{TiO}_{2}$ & 4.70 & 5.35 & 5.55 & 5.61 & - & 1.15 & 2.22 \\
\hline $\mathrm{Al}_{2} \mathrm{O}_{3}$ & 9.73 & 10.91 & 11.32 & 11.02 & - & 3.72 & 4.60 \\
\hline $\mathrm{Fe}_{2} \mathrm{O}_{3}$ & 1.35 & 1.57 & 1.67 & 1.67 & - & - & - \\
\hline $\mathrm{FeO}$ & 10.93 & 11.45 & 11.86 & 11.73 & 14.02 & 4.18 & 4.95 \\
\hline $\mathrm{MnO}$ & 0.18 & 0.20 & 0.21 & 0.21 & 0.17 & 0.01 & 0.01 \\
\hline $\mathrm{MgO}$ & 11.24 & 8.86 & 8.51 & 8.52 & 44.59 & 15.51 & 14.31 \\
\hline $\mathrm{CaO}$ & 17.01 & 17.35 & 16.93 & 16.91 & 0.34 & 23.12 & 24.02 \\
\hline $\mathrm{Na}_{2} \mathrm{O}$ & 1.49 & 1.71 & 1.81 & 1.65 & - & 0.23 & 0.15 \\
\hline $\mathrm{K}_{2} \mathrm{O}$ & 1.26 & 1.46 & 1.56 & 1.62 & - & - & - \\
\hline $\mathrm{P}_{2} \mathrm{O}_{5}$ & 0.45 & 0.52 & 0.55 & 1.18 & - & - & - \\
\hline $\mathrm{F}$ & 0.13 & 0.15 & 0.16 & 0.18 & - & - & - \\
\hline $\mathrm{CO}_{2}$ & 0.10 & 0.12 & 0.13 & 0.51 & - & - & - \\
\hline $\mathrm{S}$ & 0.02 & 0.02 & 0.02 & 0.02 & - & - & - \\
\hline Total & 100.00 & 100.00 & 100.00 & 100.00 & 100.00 & 100.00 & 100.00 \\
\hline $\mathrm{mg \#}$ & 64.72 & 57.99 & 56.14 & 56.43 & & & \\
\hline Fo & & & & & 85.0 & & \\
\hline En & & & & & & 45.4 & 41.7 \\
\hline Wo & & & & & & 47.9 & 50.3 \\
\hline
\end{tabular}

composition cannot be derived by fractionation of olivine and clinopyroxene from melteigite melt. Furthermore, melteigite crystallization modelling shows that to approach the REE concentrations of residual melt similar to those of the ijolite, solidification of $c$. 22 wt. \% of parental melt is needed. Based on the fractional crystallization model, only clinopyroxene should have crystallized in this range (after removal of $14 \mathrm{wt}$ \% olivine + clinopyroxene in the first step). At the second step of this simple model, 6 wt. \% clinopyroxene was removed from the recalculated bulk rock composition; a representative $\mathrm{Ca}$, $\mathrm{Fe}, \mathrm{Al}$ and Ti-rich clinopyroxene composition (Tab. 5) was adopted for calibration of this model. Removing 6 wt. \% clinopyroxene provides the best fit between modelled major-elements bulk-rock composition and the real ijolite analysis (Tab 5, Fig. 9). Total removal of $20 \%$ olivine and clinopyroxene from the melteigite bulk rock composition is very close to the estimation based on modelled REE concentration evolution during equilibrium and fractional crystallization of the melteigite parental melt. It is apparent that derivation of ijolite parental melt from melteigite is possible only for conditions of olivine and clinopyroxene fractionation during the early crystallization phase and also with partial crystallization during magma ascent (that is, pressure decrease).

\section{Conclusions}

(i) Crystallization modelling of ijolitic rocks excludes the presence of any significant amounts of accumulated minerals and confirms that the modelled majorelement bulk-rock compositions reflect their parental magma compositions very well.

(ii) Chemical zoning of clinopyroxenes in melteigite and ijolite resulted from substitution of $\mathrm{Fe}^{2+}+\mathrm{Ti}^{4+}+2 \mathrm{Al}$ for $2 \mathrm{Mg}+2 \mathrm{Si}$, which led most likely to significant enrichment of clinopyroxenes in $\mathrm{Al}$ and $\mathrm{Ti}$ in the course of the crystallization. Significance of this substitution mechanism points to a rapid pressure decrease associated with the magma ascent.

(iii) The chemical composition of melteigite clinopyroxenes, together with the results of crystallization modelling, indicates early equilibrium crystallization at $c .4$ kbar followed by low-pressure fractional crystallization ( $\sim .2 \mathrm{kbar})$. For ijolite, the results indicate solely low-pressure fractional crystallization, probably at the final emplacement level.

(iv) Strong REE variations between core, mantle and rim of clinopyroxene grains in both rock samples suggest formation of these rocks by fractional crystallization processes, and correspond very well with the results 
of crystallization modelling. The limited compositional variability in $\mathrm{Mg}$-rich clinopyroxene cores from melteigite indicates early equilibrium crystallization under higher temperature and pressure. Low minimum cooling rate estimated for melteigite $\left(175^{\circ} \mathrm{C} / \mathrm{yr}\right.$; $\sim 0.02{ }^{\circ} \mathrm{C} / \mathrm{hr}$ ), based on the variation of Fo content in olivine, suggests that this rock has been emplaced and crystallized at a greater depth.

(v) The correspondence between measured bulk-rock REE contents and calculated equilibrium melt REE compositions for melteigite and ijolite, suggests that the bulk-rock REE budget of both ijolitic rocks reflects the composition of the original parental melt accurately. The bulk-rock chemistry of these rocks excludes the presence of significant amounts of accumulated minerals and was not affected by removal of putative REE-enriched residual melt by filter-pressing after emplacement, neither. Therefore, these rocks were likely to have evolved solely by the closed-system fractional crystallization.

(vi) The results of crystallization modelling and parental melts REE composition estimations suggest a close genetic relationship between both studied ijolitic rocks. Removal of $\sim 20 \%$ of olivine and clinopyroxene from the initial melt provides a feasible mechanism for the derivation of fractionated ijolite magma from that of the melteigite.

Acknowledgements. This research was supported by project IAA300130612 granted by the Grant Agency of the Czech Academy of Sciences (GAAV). The study was conducted within the framework of research plans of the Czech Geological Survey (MZP0002579801) and Faculty of Science, Charles University in Prague (MSM0021622855). We would like to thanks to journal reviewers, Axel Renno and Alan Wolley, for their careful critical reviews as well as to Associate Editor David Dolejš for constructive comments and suggestions which significantly improved the quality of the paper.

\section{References}

Anders E, Grevesse N (1989) Abundances of the elements: meteoritic and solar. Geochim Cosmochim Acta 53: 197-214

Babuška V, Fiala J, Plomerová J (2010) Bottom to top lithosphere structure and evolution of western Eger Rift (central Europe). Int J Earth Sci 99: 891-907

BÉDARD JH (2005) Partitioning coefficients between olivine and silicate melts. Lithos 83: 394-419

Boudreau AE (1999) A version of the MELTS software program for the PC platform. Comput and Geosci 25: $21-203$
Bourgeois O, Ford M, Diraison M, Le Carlier De Veslud C, Gerbault M, Pik R, Ruby N, Bonnet S (2007) Separation of rifting and lithospheric folding signatures in the NW-Alpine foreland. Int J Earth Sci 96: 1003-1031

Buddington AF, Lindsley DH (1964) Iron-titanium oxide minerals and synthetic equivalents. J Petrol 5: 310-357

Buening DK, Buseck PR (1973) Fe-Mg lattice diffusion in olivine. J Geophys Res 78: 6852-6862

Dèzes P, Schmid SM, Ziegler PA (2004) Evolution of the European Cenozoic Rift System: interaction of the Alpine and Pyrenean orogens with their foreland lithosphere. Tectonophysics 389: 1-33

FeJFAR O, KaISER TM (2005) Insect bone-modification and paleoecology of Oligocene mammal-bearing sites in the Doupov Mountains, northwestern Bohemia. Palaeon Electron 8.1.8A: 1-11, http://palaeo-electronica. org/2005_1/fejfar8/fejfar8.pdf

GHIORso MS (1985) Chemical mass transfer in magmatic processes. I. Thermodynamic relations and numerical algorithms. Contrib Mineral Petrol 90: 107-120

Ghiorso MS, SACK RO (1994) Chemical mass transfer in magmatic processes. IV. A revised and internally consistent thermodynamic model for the interpolation and extrapolation of liquid-solid equilibria in magmatic systems at elevated temperatures and pressures. Contrib Mineral Petrol 119: 197-212

HART SR, DunN T (1993) Experimental Cpx/melt partitioning of 24 trace elements. Contrib Mineral Petrol 113: 1-8

Hollocher K, RuIz J (1995) Major and trace element determinations on NIST glass standard reference materials $611,612,614$ and 1834 by inductively coupled plasmamass spectrometry. Geost Geoanal Res 19: 27-34

Holub FV, Rapprich V, Erban V, Pécskay Z, Mlčoch B (2010) Petrology and geochemistry of alkaline intrusive rocks at Doupov, Doupovské hory Mts. J Geosci 55: 251-278

Kress VC, Carmichael ISE (1988) Stoichiometry of the iron oxidation reaction in silicate melts. Amer Miner 73: $1267-1274$

KRETZ R (1983) Symbols for rock-forming minerals. Amer Miner 68: 277-279

Lustrino M, WiLSON M (2007) The circum-Mediterranean anorogenic Cenozoic igneous province. Earth Sci Rev 81: $1-65$

McSween Hy, Eisenhour DD, Taylor LA, Wadhwa M, CROZAZ G (1996) QUE94201 shergottite: crystallization of a Martian basaltic magma. Geochim Cosmochim Acta 60: 4563-4569

MlČoch B, KonopáseK J (2010) Pre-Late Carboniferous geology along the contact of the Saxothuringian and Teplá-Barrandian zones in the area covered by younger sediments and volcanics (western Bohemian Massif, Czech Republic). J Geosci 55: 81-94 
Nimis P (2007) A clinopyroxene geobarometer for basaltic systems based on crystal-structure modeling. Contrib Mineral Petrol 121: 115-125

RAJChl M, UliČNÝ D, GRYGAR R, MACH K (2009) Evolution of basin architecture in an incipient continental rift: the Cenozoic Most Basin, Eger Graben (Central Europe). Basin Res 21: 269-294

RAPPRICH V (2005) Compositional variation of clinopyroxenes of basaltic, essexitic and tephriphonolitic rocks from the Doupovské hory Volcanic Complex, NW Bohemia. J Czech Geol Soc 50: 119-132

RAPPRICH V, Holub FV (2008) Geochemical variations within the Upper Oligocene-Lower Miocene lava succession of Úhošt' Hill (NE margin of Doupovské hory Mts., Czech Republic). Geol Quart 52: 253-268

Roeder PL, Emslie RF (1970) Olivine-liquid equilibrium. Contrib Mineral Petrol 29: 275-289
Schmidt NH, Olensen NO (1989) Computer-aided determination of crystal-lattice orientation from electron-channelling patterns in the SEM. Canad Mineral 28: 15-22

SKÁCElOVÁ Z, RAPPRich V, MLČOCH B (2009) Effect of small potassium-rich dykes on regional gamma-spectrometry image of a potassium-poor volcanic complex: a case from the Doupovské hory Volcanic Complex, NW Czech Republic. J Volcanol Geotherm Res 187: 26-32

TAylor LA, Onorato PIK, Uhlmann DR (1977) Cooling rate estimations based on kinetic modeling of $\mathrm{Fe}-\mathrm{Mg}$ diffusion in olivine. In: Proceedings of the $8^{\text {th }}$ Lunar Science Conference, Lunar and Planetary Institute, Houston, pp 1581-1592

TRACY RJ, RoBINSON P (1977) Zoned titanian augite in alkali olivine basalt from Tahiti and nature of titanian substitutions in augite. Amer Miner 62: 634-645

Wiesbaur JB (1901) Theralith im Duppauer Gebirge. Lotos 21: $62-71$ 